This is a "preproof" accepted article for Journal of Financial and Quantitative Analysis. This version may be subject to change during the production process.

DOI: $10.1017 / S 002210902000037 X$

\title{
Overconfident Institutions and Their Self-Attribution Bias: Evidence from Earnings Announcements
}

\author{
Hsin-I Chou, Mingyi Li, Xiangkang Yin, and Jing Zhao*
}

* Chou, daisy.chou@,rmit.edu.au, RMIT University School of Economics, Finance and Marketing; Li, mingyi.li@griffith.edu.au, Griffith University Department of Accounting, Finance and Economics; Yin, xiang.yin@deakin.edu.au, Deakin University Department of Finance; and Zhao (corresponding author), j.zhao@latrobe.edu.au, La Trobe University Department of Economics, Finance and Marketing. We thank Linquan Chen, Edward Podolski, Ian Tonks, Jiaguo (George) Wang, seminar participants at the University of Bath and Deakin University, and conference participants at the 2016 Conference on the Theories and Practices of Securities and Financial Markets and the 2017 European Financial Management Association Annual Meeting for their highly valued comments. We are particularly grateful to Hendrik Bessembinder (the editor), Roger Edelen and Paul Irvine (the referees), and Avanidhar Subrahmanyam, whose comments and suggestions have substantially improved the paper. This project is supported by the Discovery Projects funding provided by the Australian Research Council (DP140100113). 


\begin{abstract}
Institutional demand for a stock prior to its earnings announcement is negatively related to subsequent returns. The relationship is not attributable to the price pressure of institutional demand and is stronger for stocks with higher information asymmetry and/or greater valuation difficulty. These findings support the notion of overconfident institutions mispricing stocks. Following announcements, institutions' behavior exhibits the outcome-dependent feature of self-attribution bias. Whether they become more overly confident and delay their mispricing correction depends on whether earnings news confirms their pre-announcement trades or not. This behavioral bias also offers a new explanation for the well-known anomaly of post-earnings-announcement drift.
\end{abstract}




\section{Introduction}

Earnings are regularly announced according to preset schedules, which is arguably one of the most important corporate events since these announcements release substantial amounts of information concerning corporations' fundamentals. The released information provides essential measures for investors to evaluate their investment decisions. This paper studies institutional demand around earnings announcements, focusing on how it reacts to announcements and how it manifests in stock returns.

We begin by documenting that the Cumulative Abnormal Institutional Demand (CAID) for a stock prior to its earnings announcement is negatively related to the stock's subsequent Cumulative Abnormal Return (CAR). A key and well-known feature of institutional demand is price pressure, which may cause subsequent returns to reverse. ${ }^{1}$ Could this price pressure explain the observed negative relationship between CAID and subsequent CAR around earnings announcements? To answer this question, we run placebo tests by contrasting the relationships between pre-announcement CAID and post-announcement CAR around actual and pseudo earnings announcements. They demonstrate that price pressures prior to actual and pseudo announcements are quite similar, while subsequent stock returns are significantly different. This implies that the identified negative return predictability by pre-announcement CAID cannot be simply attributed to price pressure effect.

Another possibility for the return reversal is that mispricing caused by overconfident institutions gets corrected after earnings news is released. Institutional investors are likely to be overconfident about their valuations of risky securities and their trading skills, and such behavioral

\footnotetext{
${ }^{1}$ Studies documenting price pressure associated with institutional trading include: firstly, Keim and Madhavan (1995) and Chan and Lakonishok (1997) at a stock level; and secondly, Warther (1995) and Edelen and Warner (2001) at the aggregate level.
} 
bias leads them to overreact to their information and knowledge, causing stocks to be mispriced in the pre-announcement period. We support this claim with evidence of institutions being a driving force of setting stock prices as manifested by the strong and positive contemporaneous relationship between CAID and CAR. More importantly, the overconfidence theory developed by Daniel, Hirshleifer, and Subrahmanyam (1998) implies stronger return predictability in stocks with greater information asymmetry. Moreover, psychological evidence indicates that overconfidence is more severe for diffuse tasks, which require judgement, than for mechanical tasks. ${ }^{2}$ Consistent with these theories and in supporting the overconfidence explanation, we find that the negative relationship between pre-announcement CAID and subsequent CAR is stronger for stocks with greater difficulty to value and higher information asymmetry. These findings are robust and remain even after controlling for earnings announcement premium (Savor and Wilson (2016)) and news-driven return reversal (So and Wang (2014)), which support the notion of institutions being subject to overconfidence bias. ${ }^{3}$

The self-attribution hypothesis is probably a more powerful test for overconfident institutions, because biased self-attribution is related to variation in confidence level, which is outcome-dependent and cannot be explained by price pressure in the market. Biased selfattribution causes the shifts in an investor's confidence level to be asymmetric with respect to her/his investment outcomes and explains how overconfidence can persist over time (Daniel and Hirshleifer (2015)). To test the hypothesis, we consider two consecutive periods after an earnings announcement. We observe that stocks associated with confirming earnings news experience much weaker correction of mispricing in the earlier period, compared to stocks with disconfirming

\footnotetext{
2 See, e.g., Einhorn (1980) and Griffin and Tversky (1992).

3 To economize the size of the paper, these robustness tests are not reported in the text but in the Supplementary Material.
} 
news. Moreover, they endure continued correction in the later period while correction for the stocks with disconfirming news tends to be completed in the earlier period. Apart from this, the magnitude of earnings surprise also matters: a greater confirming (disconfirming) earnings surprise leads to a weaker (stronger) mispricing correction in the earlier period. These results demonstrate that institutions asymmetrically update their confidence based on their investment outcomes, and more favorable (unfavorable) earnings news causes their confidence to rise (fall) more.

To further the validity of our evidence, we test for institutions' biased self-attribution by examining their post-announcement trading. Institutions tend to continue their pre-announcement trading directions for a period after confirming earnings announcements, in contrast to more timely changing their trading directions after disconfirming earnings announcements. Moreover, their trading patterns become more asymmetric when the magnitude of earnings surprise increases. Similar trading dynamics are also observable in terms of the probability of individual institutions continuing or altering their pre-announcement trading directions.

Biased trading behavior of overconfident institutions around earnings announcements also offers a novel explanation for the well-known anomaly of Post-Earnings-Announcement Drift (PEAD). We find that the PEAD phenomenon is strong (weak or even disappears) when earnings news disconfirms (confirms) pre-announcement institutional trades, which is consistent with institutions' asymmetric reactions to confirming and disconfirming news as a result of their biased self-attribution.

Empirical examination and evidence of investor overconfidence in the existing literature are largely limited to individual investors, except for Statman, Thorley, and Vorkink (2006) who consider aggregate overconfidence of all investors as a whole. Relative to typical individual investors, institutions are more sophisticated since: firstly, they have more resources to collect, 
process and analyze information; and secondly, their managers are better trained and more skillful in making investment decisions. Would this financial and technological sophistication help institutional investors to avoid or alleviate behavioral or emotional bias? The lack of explicit evidence of institutions being overconfident seems to suggest they are mostly rational. This perception, however, is questionable. Our findings support the claim that overconfidence is pervasive and experts can be overconfident (Daniel et al. (1998)). ${ }^{4}$

Our finding of negative return predictability by pre-announcement CAID provides complementary evidence to previous studies which document a negative relationship between institutional trading and future stock return. For instance, Edelen, Ince, and Kadlec (2016) show that changes in the number of $13 \mathrm{~F}$ institutional investors over the prior 5 quarters are negatively correlated with abnormal stock return over the 3 days surrounding earnings announcements. On the other hand, there are studies demonstrating that changes in institutional holdings are positively related to future stock returns. For instance, Baker, Litov, Wachter, and Wurgler (2010) demonstrate that stocks in which active mutual funds have increased (decreased) weight in the quarter prior to earnings announcements earn positive (negative) abnormal returns over the 3 days surrounding earnings announcements. Edelen et al. (2016) attribute this difference in terms of the relationships being positive and negative to the length of the horizon over which returns and demand are measured. Different from these studies using quarterly institutional holding data, we adopt ANcerno data that record each individual transaction conducted by its clients, which helps us to examine how institutions trade prior to and in reaction to earnings announcements with greater precision. ${ }^{5}$ Additionally, we focus on the associations of CAID over the relatively short

\footnotetext{
${ }^{4}$ For psychological evidence of experts being more overconfident than inexperienced individuals, see, for example, Griffin and Tversky (1992), Keren (1997), and Koehler, Brenner, and Griffin (2002).

${ }^{5}$ Our study differs from Baker et al. (2010) in terms of the types of institutional investors under investigation. Puckett and Yan (2011) show that ANcerno data are representative of the institutional investors who file Form 13F. Thus, our
} 
horizons (from 10 to 40 days) prior to earnings announcements with the CARs and CAIDs over the announcement and various post-announcement periods up to 120 days.

Our findings also contribute to the growing literature on stock return anomalies by connecting institutional trading with market mispricing. The PEAD anomaly was first documented by Ball and Brown (1968) and recognized as one of the most robust asset pricing anomalies (Fama (1998)). Although Daniel et al. (1998) offer a theoretical explanation for the PEAD anomaly based on investor overconfidence and biased self-attribution, empirical evidence on its cause is mixed and whether individual or institutional investors are responsible for it remains an open question. For instance, Hirshleifer, Myers, Myers, and Teoh (2008) find no evidence that individual investors cause the PEAD anomaly, while Ke and Ramalingegowda (2005) provide evidence that transient institutional investors trade to exploit the PEAD. Unlike prior studies that examine whether individual or institutional investors trade in the direction of earnings surprises after earnings are announced, we focus on institutions' responses to earnings announcements conditional on their pre-announcement trading. The new finding that overconfident institutions are, at least partially, responsible for the PEAD anomaly complements the existing explanations for the PEAD anomaly.

The remainder of this paper is organized as follows. Section II describes data, variables, and sample characteristics. Price pressures and overconfident institutions are examined in Section III while the self-attribution hypothesis is tested in Section IV. Section V examines overconfidence and biased self-attribution using post-announcement CAID and Section VI provides an alternative explanation for the PEAD anomaly. Robustness checks are reported in Section VII. The final section concludes the paper.

data include a much wider spectrum of institutional investors. In addition, their use of quarterly holding data introduces return gap effects, which do not necessarily exist in our analysis that uses transaction-level data. 


\section{Data, Variables, and Sample Characteristics}

\section{A. Sample Selection}

The data for stock purchases and sales by institutional investors are obtained from ANcerno, which records each individual transaction conducted by its clients. Variables in each transaction record include the following: a masked ID of institution that initiates a trade, ticker and CUSIP of the traded stock, date of execution, execution price, execution volume, whether it is a buy or sell transaction, commissions paid to brokers, etc. During our sample period from January 2000 to June 2013, there are a total of 956 buy-side institutions. To minimize observation errors, we follow Anand, Irvine, Puckett, and Venkataraman (2012) and impose two screens on the ANcerno data: (i) delete orders with a volume greater than the stock's CRSP volume on an execution date; and (ii) only include common stocks (with share codes of 10 and 11) listed on NYSE, AMEX, NASDAQ with data available on CRSP. We collect stock price, return, market capitalization, and trading volume data from CRSP, accounting data from Compustat, and earnings announcement and analyst forecast information from $\mathrm{I} / \mathrm{B} / \mathrm{E} / \mathrm{S}$. For each announcement, we require at least 40 days of data prior to it and 120 days of data after it. We consider the pre-announcement period from day -40 to day -1 , the announcement period from day 0 to day 1 and various postannouncement periods. ${ }^{6}$ To reduce the effect of the subsequent announcement in the postannouncement period, we exclude announcements with no more than 60 days between two consecutive announcements. $^{7}$

\footnotetext{
${ }^{6}$ In robustness checks reported in the Supplementary Material, we further consider different pre-announcement periods such as $[-30,-1],[-20,-1],[-10,-1]$ and replicate the key analysis and tests. Since they lead to qualitatively similar results, we do not explicitly spell these tests out in the text. Announcement day is defined as day 0. Both day 0 and day 1 are included in the announcement period to control for the effect of after-hour announcements. Following the convention of the PEAD literature, we choose the baseline post-announcement period from day 2 through day 60 and in turn a corresponding later period of day 61 through day 120. We also include other pairs of earlier and later post-announcement periods in our analysis.

${ }^{7}$ Our findings are qualitatively similar if we include these announcements in the sample.
} 


\section{B. Abnormal Institutional Demand}

To characterize abnormal institutional demand, we first calculate daily imbalance by

$$
\mathrm{IM}_{i, t}=\frac{\text { BUYVOLUME }_{i, t}-\operatorname{SELLVOLUME}_{i, t}}{\text { BUYVOLUME }_{i, t}+\operatorname{SELLVOLUME}_{i, t}}
$$

where BUYVOLUME $i, t\left(\operatorname{SELLVOLUME}_{i, t}\right)$ is the number of shares purchased (sold) by ANcerno institutions for stock $i$ on day $t$. Then, the abnormal institutional demand on that day can be proxied by the standardized volume imbalance:

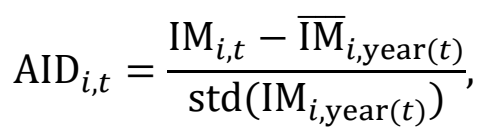

where year $(t)$ denotes the year of which day $t$ belongs to and $\overline{\mathrm{IM}}_{i, \text { year( }(t)}$ and $\operatorname{std}\left(\mathrm{IM}_{i, \text { year( }(t)}\right)$ are sample mean and standard deviation of $\mathrm{IM}_{i, t}$ over year $(t)$. Consequently, cumulative abnormal institutional demand over period $\left[t_{1}, t_{2}\right]$ is defined as $\operatorname{CAID}_{i,\left[t_{1}, t_{2}\right]}=\sum_{k=t_{1}}^{t_{2}} \operatorname{AID}_{i, k}$.

\section{Abnormal Return and Earnings Surprise}

We adopt the size-adjusted benchmark to measure abnormal return. At the beginning of each year, we sort all stocks in NYSE, NASDAQ, and AMEX into deciles based on their market capitalizations. The daily abnormal return of stock $i$ is the difference between its raw return and the average return of all stocks located in the same size decile, i.e., $\mathrm{AR}_{i, t}=R_{i, t}-R_{p, t}$, where $R_{i, t}$ is the raw return of stock $i$ on day $t$ and $R_{p, t}$ is the average return of all stocks located in the same size decile as stock $i$. Cumulative abnormal return is estimated by aggregating abnormal returns over the evaluation window, i.e., $\mathrm{CAR}_{i,\left[t_{1}, t_{2}\right]}=\sum_{k=t_{1}}^{t_{2}} \mathrm{AR}_{i, k}$.

We use Standardized Unexpected Earnings (SUE) to proxy for earnings surprise. ${ }^{8}$ It is calculated as the difference between the actual quarterly earnings and the mean analyst forecast,

\footnotetext{
${ }^{8}$ Our findings are qualitatively similar if we use market reaction over the announcement period, i.e., the cumulative abnormal return from day 0 to day 1 , as a proxy for earnings surprise.
} 
divided by the standard deviation of all analyst forecasts. Thus, a positive (negative) SUE measures a positive (negative) market surprise and both very high and very low SUEs indicate big shocks to the market.

\section{Sample Descriptive Statistics}

Our final sample includes 83,355 quarterly earnings announcements of 5,604 stocks over the 13.5 years of the sample period. Table 1 presents the summary statistics of sample characteristics and key variables used in the analysis. For each announcement, market capitalization (MKTCAP), ${ }^{9}$ stock price (PRICE), and bid-ask spread (SPREAD) are measured as their daily closing averages. ILLIQUIDITY is measured by the average daily Amihud (2002) illiquidity ratio, multiplied by a factor of 1,000,000. Market beta (BETA) is estimated from regressing daily excess return on the Fama-French 3 factors, while idiosyncratic volatility (IDIOV) is the standard deviation of the residuals. Institutional ownership (INST) of a stock is the average fraction of shares outstanding held by institutions filing Form 13F, analyst coverage (ACOVERAGE) is the average number of analysts following the stock on $\mathrm{I} / \mathrm{B} / \mathrm{E} / \mathrm{S}$, dispersion in analyst forecasts (DISP) is the standard deviation of analysts forecasts, book-to-market ratio (BM) is the average book-to-market ratio computed as book value of equity divided by market value of equity, and firm age (AGE) is the number of years since the stock first appears in the CRSP database. Probability of information-based trading (PIN) is estimated based on the model of Easley, Kiefer, and O'Hara (1997) and obtained from Stephen Brown's personal website. ${ }^{10}$ All these measures of

\footnotetext{
${ }^{9}$ The logarithm of market capitalization proxies for firm size (SIZE) in the regression analysis.

${ }^{10}$ We thank Stephen Brown for making estimated PIN measure available on his personal website, which is adopted in Brown and Hillegeist (2007), and Brown, Hillegeist, and Lo (2009) for examining information asymmetry. In the unreported analysis, we use the PIN measure estimated based on the model of Venter and de Jongh (2006) and obtain qualitatively similar results.
} 
stock characteristics are estimated using the data in the year prior to the announcement and they are included in our regression analysis as control variables.

\section{INSERT TABLE 1 HERE}

We also consider a set of other stock characteristics, including: turnover (TO), the average daily trading volume divided by the number of shares outstanding; research and development intensity ( $R \& D)$, the firm's R\&D expenditures divided by its total assets; earnings quality (EARNINGSQ), the negative absolute value of industry-adjusted operating accruals for the firm; cash flow volatility (CASHFLOWV), the volatility of the firm's operating cash flows scaled by its total assets during the past 5 years; and earnings volatility (EARNINGSV), the volatility of the firm's earnings before extraordinary items scaled by its total assets during the past 5 years. ${ }^{11}$

We winsorize the raw SUE scores and stock characteristics at the top and bottom $0.5 \%$ to reduce the impact of extreme values. ${ }^{12}$ In Table 1 , we also report CAR and CAID over the preannouncement, announcement and post-announcement periods.

\section{III.Institutional Demand and Stock Returns}

\section{A. Pre-Announcement Institutional Demand and Stock Returns Around the Announcement}

We sort sample stocks into quintiles based on the pre-announcement abnormal institutional demand from day -40 to day -1 , i.e., $\operatorname{CAID}_{[-40,-1]}$, with $\mathrm{Q} 5$ (Q1) being the quintile of stocks strongly bought (sold) by institutions. Panel A of Table 2 reports their average pre-announcement, announcement and post-announcement CARs. During the pre-announcement period, stocks strongly bought by institutions outperform those strongly sold by 354 base points (bps). This strong positive contemporaneous relationship between CAID and CAR implies that institutional

\footnotetext{
${ }^{11}$ In unreported robustness checks of regression analysis, we further include these stock characteristics as controls and find qualitatively similar results.

${ }^{12}$ Our results remain qualitatively similar if we do not winsorize the SUE scores and stock characteristics.
} 
demand is a driver of stock price and institutions play a dominant role in the stock market. Turning to subsequent returns, we find significantly negative relationships since CARs over all the subsequent periods in Panel A increase when stock quintile moves from Q5 to Q1. CARs of stocks in Q5 underperform those of stocks in Q1 by an average of 78 bps over the announcement period of days 0 and 1 . The difference is 61 bps during day 2 to day 6 and this remains significant even if we extend the evaluation time horizon to $[2,60] .{ }^{13}$

\section{INSERT TABLE 2 HERE}

One could argue that the observed negative relationships between CAID and subsequent CARs simply reflect return reversal (Jegadeesh (1999)) and/or the effects of some firm characteristics. To address this concern, we run the following regression:

$$
\operatorname{CAR}_{\left[t_{1}, t_{2}\right]}=\beta_{0}+\beta_{1} \operatorname{CAID}_{[-40,-1]}+\beta_{2} \operatorname{CAR}_{[-40,-1]}+\sum_{\mathrm{i}=1}^{12} \gamma_{i} \mathrm{CV}_{i}+\varepsilon,
$$

where standard return reversal is captured by $\mathrm{CAR}_{[-40,-1]}$ and controls for 12 stock characteristics of the prior year (i.e., $\mathrm{CV}_{i}$ ) include: stock size, stock price, stock illiquidity, market beta, idiosyncratic volatility, bid-ask spread, institutional ownership, analyst coverage, book-to-market ratio, probability of information-based trading, firm age, and dispersion in analyst forecasts. The regression results are reported in Panel B of Table 2, where 2-way cluster-robust t-statistics are presented in parentheses. Apparently, $\operatorname{CAID}_{[-40,-1]}$ has a significantly positive relationship with $\operatorname{CAR}_{[-40,-1]}$ and a significantly negative relationship with each subsequent CAR. It verifies our findings through the nonparametric analysis in Panel A. Kaniel, Liu, Saar, and Titman (2012) in their study on the trading of individual investors around earnings announcements discover that intense aggregate buying (selling) by individual investors predicts large positive (negative)

\footnotetext{
${ }^{13}$ In unreported robustness checks, we extend the post-announcement period to $[2,70],[2,80],[2,90]$, and [2,120], and obtain qualitatively similar results in both nonparametric and regression analyses.
} 
abnormal returns on and after earnings announcement dates. To the extent that institutional investors are the counterpart of individual investors as a whole, our findings are consistent with theirs, as well as those of Busse, Green, and Jegadeesh (2012) and Griffin, Shu, and Topaloglu (2012) who find little or no evidence of information advantages owned by institutional investors.

\section{B. Price Pressure Effect of Institutional Trading?}

Abnormal institutional trading in the pre-announcement period is likely to exert demand pressures on the stocks so that their prices overshoot, and consequently the returns of the stocks revert to the fundamentals after earnings are announced. Could the negative relationship between pre-announcement CAID and subsequent CAR be the outcome of price pressure associated with institutional trading? To answer this question, we conduct placebo tests to compare the relationships between CAID and CAR around actual and pseudo earnings announcements. For each actual earnings announcement, the pseudo announcement date is determined by subtracting a random number of trading days from the actual announcement date, which is drawn from a uniform distribution spanning from 21 to 39 . We consider pre- and post-announcement periods up to 20 days so that they do not overlap with the actual announcement date.

Panel A of Table 3 sorts actual and pseudo earnings announcements into quintiles based on $\mathrm{CAID}_{[-20,-1]}$. It first reports the CAID or CAR difference between Q5 and Q1 over various periods and then tests difference in differences, i.e., the difference between the actual and pseudo announcements in the differences between Q5 and Q1. The first and second columns report CAID and CAR in the pre-announcement period (i.e., the sorting period), and their differences between actual and pseudo earnings announcements are statistically insignificant, which indicates similar effects of price pressure across the two types of announcements. The third to sixth columns report subsequent returns. The differences between Q5 and Q1 are significantly negative for actual 
earnings announcements but marginally or not significantly for pseudo earnings announcements. The difference-in-difference tests confirm the significant difference between actual and pseudo announcements. For instance, the fourth column shows that the difference in $\operatorname{CAR}_{[2,6]}$ between $\mathrm{Q} 5$ and Q1 is $-46(-15)$ bps for actual (pseudo) earnings announcements, and the difference-indifference is -31 bps. The significant difference-in-difference implies that the strong negative association between pre-announcement CAID and subsequent CAR around actual earnings announcements are not driven by price pressure in the market since the price pressures around actual and pseudo announcements are not significantly different.

\section{INSERT TABLE 3 HERE}

In Panel B of Table 3, we use the regression specified by equation (3) to regress subsequent CAR against pre-announcement CAID on the sample of pseudo earnings announcements. In contrast to the strong negative return predictability by CAID in the pre-announcement period of actual earnings, there is no return predictability by the pre-announcement CAID of pseudo earnings announcements. This further confirms the difference between actual and pseudo earnings announcements. Table A2 in the Supplementary Material adopts a 10-day pre-announcement period and obtains results qualitatively similar to Table 3 .

\section{Overconfident Institutions?}

An alternative explanation for the return reversal around earnings announcements is the overconfidence of institutional investors. Investors are subject to psychological bias and overconfidence is arguably one of the most prominent phenomena of behavioral bias. Existing studies have found a negative association between changes in quarterly institutional ownership and long-term future stock returns, which is used by these authors as evidence of institutions' 
behavioral bias such as herding. ${ }^{14}$ Since information released at an earnings announcement is more likely to correct mispricing relative to other possible releases (Bernard, Thomas, and Wahlen (1997)), these announcements provide us with remarkable opportunities to examine whether return reversals around earnings announcements are driven by the overconfidence of institutions and their trading to correct mispricing. The logic behind the conjecture is that if institutions are overconfident in their information and knowledge prior to earnings announcements, their abnormal buys (sells) are likely to push the stock price above (below) the fundamentals, as illustrated in Graph A (Graph B) of Figure 1. They may start to correct their errors when the earnings are announced, which drives the stock price back to the fundamentals.

\section{INSERT FIGURE 1 HERE}

The significantly positive contemporaneous relationship between CAID and CAR documented in Table 2 demonstrates institutional demand is a key determinant of stock prices and it leads stock prices in the pre-announcement period to deviate from their fundamental values. This mispricing is partially and gradually corrected upon news arrivals when earnings are announced. Thus, the negative relationship of pre-announcement CAID with post-announcement CAR can be interpreted as empirical evidence supporting the argument of institutional investors being overconfident. Moreover, pseudo earnings announcements do not bring new information and in turn, they, as shown in Table 3, do not lead to mispricing correction.

While the negative relationship between CAID and subsequent CAR indicates that institutional investors are likely to be overconfident, their mispricing in the pre-announcement period is reconfirmed if we can verify that institutions trade to correct this mispricing in the postannouncement period. For this reason, we examine whether institutions' trading moves stock price,

\footnotetext{
${ }^{14}$ See Dasgupta, Prat, and Verardo (2011), Brown, Wei, and Wermers (2014), and Edelen et al. (2016).
} 
i.e., whether their trading direction is in line with return pattern, in the post-announcement period by the following regression:

$$
\operatorname{CAR}_{\left[t_{1}, t_{2}\right]}=\beta_{0}+\beta_{1} \operatorname{CAID}_{\left[t_{1}, t_{2}\right]}+\beta_{2} \operatorname{CAID}_{\left[t_{1}^{*}, t_{2}^{*}\right]}+\beta_{3} \operatorname{CAR}_{\left[t_{1}^{*}, t_{2}^{*}\right]}+\sum_{i=1}^{12} \gamma_{i} \mathrm{CV}_{i}+\varepsilon
$$

Table A3 in the Supplementary Material reports the regression for the three post-announcement periods of $\left[t_{1}, t_{2}\right]=[2,20],[2,40]$, and $[2,60]$ with controlling of $\operatorname{CAID}_{\left[t_{1}^{*}, t_{2}^{*}\right]}$ and $\operatorname{CAR}_{\left[t_{1}^{*}, t_{2}^{*}\right]}$ for $\left[t_{1}^{*}, t_{2}^{*}\right]=[-40,-1],[-30,-1],[-20,-1]$, and $[-10,-1]$, respectively. All $\beta_{1}$ estimates are positive and significant at the $1 \%$ level, confirming that institutional demand is a driver of stock prices in all post-announcement periods considered, which is consistent with the dominant role of institutional investors in the stock market. It also implies that institutions' pre-announcement mispricing is gradually corrected when earnings news and other subsequent public information are released. More importantly, it validates our tests for the self-attribution hypothesis below based on their implications for stock return patterns.

\section{Effects of Information Asymmetry and Valuation Difficulty}

The overconfidence theory of Daniel et al. (1998) takes private information into account and implies stronger return predictability in stocks with greater information asymmetry. On the other hand, psychological evidence indicates that overconfidence is more severe for diffuse tasks, which require judgement, than for mechanical tasks. When stocks are more difficult to value, investors tend to exhibit more overconfidence, because less hard information exists to benchmark their irrational expectations. Based on these arguments, we conjecture there is a stronger negative relationship between preannouncement CAID and subsequent CAR for stocks whose information is more asymmetric and/or whose values are harder to be accurately evaluated, if institutional investors are overconfident. To test this assertion, we estimate the following regression model:

$$
\operatorname{CAR}_{\left[t_{1}, t_{2}\right]}=\beta_{0}+\beta_{1} \operatorname{CAID}_{[-40,-1]}+\beta_{2} \operatorname{CAID}_{[-40,-1]} \times \mathrm{SC}
$$




$$
+\beta_{3} \mathrm{CAR}_{[-40,-1]}+\beta_{4} \mathrm{SC}+\sum_{i=1}^{12} \gamma_{i} \mathrm{CV}_{i}+\varepsilon
$$

It extends regression equation (3) by including SC and interaction term $\operatorname{CAID}_{[-40,-1]} \times \mathrm{SC}$, where SC denotes stock characteristics related to information asymmetry and/or difficulty of valuation, which is one of the $12 \mathrm{CV}_{i} \mathrm{~s}$ or one of the last 5 stock characteristics in Table 1 . We use the probability of informed trading (PIN) to measure information asymmetry, and idiosyncratic volatility (IDIOV) as an overall proxy for information asymmetry and valuation difficulty. ${ }^{15}$ In addition, bid-ask spread ( SPREAD), stock size (SIZE), firm age (AGE), analyst coverage (ACOVERAGE), and dispersion in analyst forecasts (DISP) are deemed to be stock characteristics related to information asymmetry and valuation difficulty. Share turnover (T0) is expected to be positively related to valuation difficulty (Banerjee (2011)), while research and development intensity (R\&D) and poor earnings quality (EARNINGSQ) are major contributors to information asymmetry (Aboody and Lev (2000), Bhattacharya, Desai, and Venkataraman (2013)) and increase valuation difficulty. Cash flow volatility (CASHFLOWV) and earnings volatility (EARNINGSV) reflect the level of uncertainty in fundamentals (Kumar (2009)).

Table 4 reports the outcomes of estimating regression equation $(5)$ for $\left[t_{1}, t_{2}\right]=[0,60] .{ }^{16}$ The estimated $\beta_{2}$ is significant at the $1 \%$ or $5 \%$ level, which indicates that the negative relationship between $\operatorname{CAID}_{[-40,-1]}$ and $\operatorname{CAR}_{[0,60]}$ is stronger for stocks with higher information asymmetry and greater valuation difficulty. To see the economic significance, let us take PIN as an example.

\footnotetext{
${ }^{15}$ Idiosyncratic volatility measures overall firm-specific return variation. It has been widely used in empirical studies to capture both information asymmetry and valuation difficulty (Moeller, Schlingemann, and Stulz (2007), Fernandes and Ferreira (2008), Jiang and Sun (2014)). Theoretically, Ferreira and Laux (2007) argue informed trade induces idiosyncratic volatility in stock returns, while Pástor and Pietro (2003) show idiosyncratic volatility increases with profitability uncertainty.

${ }^{16}$ Qualitatively similar results can be found in the Supplementary Material, where Panel A of Table A4 reports the regressions excluding control $\mathrm{CAR}_{[-40,-1]}$, Panel $\mathrm{B}$ uses different pre-announcement periods for regression equation (5), and Panels $\mathrm{C}$ and $\mathrm{D}$ consider the post-announcement periods of [2,60] and [6,60], respectively, to control for earnings announcement premium (Savor and Wilson (2016)) and news-driven return reversal (So and Wang (2014)).
} 
Column PIN shows that the regression coefficient of $\operatorname{CAID}_{[-40,-1]}$ is $-0.0007-0.0028 \times$ PIN. Thus, the negative relationship between $\operatorname{CAID}_{[-40,-1]}$ and $\mathrm{CAR}_{[0,60]}$ increases in strength by 14.7\% when PIN increases from its 25 th percentile to its median, i.e., from 0.056 to 0.101 (see Table 1 for the figures). ${ }^{17}$ Idiosyncratic volatility provides another example. When it increases from its 25 th percentile to its median, i.e., from 0.016 to 0.023 , the regression coefficient of $\operatorname{CAID}_{[-40,-1]}$ changes from -0.00024 to -0.00065 , which implies that the intensity of the negative relationship increases by $171 \%$. Among all proxies listed in Table 4, idiosyncratic volatility has the highest economic significance, which is consistent with idiosyncratic volatility being an overall proxy for information asymmetry and valuation difficulty. ${ }^{18}$ Cash flow volatility and earnings volatility are positively related to earnings predictability and therefore the results in Table 4 suggest that investors tend to be more overconfident if the forthcoming earnings are more difficult to predict.

\section{INSERT TABLE 4 HERE}

In sum, the analysis of information asymmetry and valuation difficulty provides further evidence consistent with the overconfidence of institutional investors. Since stocks with greater information asymmetry and valuation difficulty tend to be riskier to arbitrage, our results also imply limits-to-arbitrage (Shleifer and Vishny (1997)) as an important channel for overconfident institutions to affect asset prices.

\section{IV.Tests for the Self-Attribution Hypothesis}

Investors' confidence level is time-varying. Institutions' responses to earnings announcements provide great opportunities to investigate the changes in the confidence level of

\footnotetext{
${ }^{17}$ The change in the coefficient is $-0.0028 \times(0.101-0.056)=-0.000126$, which is $14.7 \%$ of the initial coefficient of $-0.0007-0.0028 \times 0.056=-0.000857$.

${ }^{18}$ The economic significances of the other proxies are not reported but available upon request.
} 
institutional investors, which are arguably irrelevant to price pressure and a range of potential explanatory variables. Psychological findings reveal that when observing the outcomes of their actions, people update their confidence in a biased manner because they are subject to selfattribution bias (Langer and Roth (1975), Taylor and Brown (1988)). Psychological and behavioral finance literature argues that biased self-attribution is an important source of overconfidence (Gervais and Odean (2001), Daniel and Hirshleifer (2015)). According to the theory developed by Daniel et al. (1998), investors' overconfidence is reinforced upon receiving confirming public information, yet decreases moderately or remains unchanged if the public information is disconfirming. In the context of earnings announcements, institutions' overconfidence is reinforced if earnings news confirms pre-announcement institutional trades (strong buy followed by good news or strong sell followed by adverse news). Thus, they keep their biased estimation of stock values shortly after earnings announcements and delay their correction of mispricing. On the other hand, if earnings news disconfirms pre-announcement institutional demand, institutions' overconfidence remains unchanged or declines by only a little. However, their incorrect estimation of stocks is reduced or discontinues after earnings announcements as they incorporate the newly released information about the fundamentals into their considerations. ${ }^{19}$ Accordingly, they act more speedily to correct mispricing. Thus, our selfattribution hypothesis asserts that stocks with confirming earnings news experience mispricing correction later than stocks with disconfirming earnings news.

To picture the self-attribution hypothesis and its tests, we illustrate the price path of a stock around its earnings announcement in the two plots in Graphs C and D of Figure 1. Graph C (Graph D) shows that following a confirming announcement the overconfidence of institutions is

\footnotetext{
${ }^{19}$ Even when an investor's confidence level remains unchanged, the arrival of new information concerning a stock's fundamentals may alter his/her valuation of the stock.
} 
reinforced and their reaction to their biased beliefs pushes stock price to continue moving up (down) over a few days immediately after the announcement. After that they start to correct the mispricing and this delay in mispricing correction results in an average stock return over an earlier postannouncement period, say day 2 to day $d_{1}$, without a clear direction. Moreover, the delayed correction endures in the later post-announcement period, $\left[d_{1}, d_{2}\right]$, leading to a return drift that is negatively related to pre-announcement institutional demand. In contrast, if the earnings news is disconfirming, institutions start to correct the mispricing in a more timely way. As the correction is likely to be completed before $d_{1}$, there is no need for further correction in the later period of $\left[d_{1}, d_{2}\right]$. Consequently, the pre-announcement institutional demand should be negatively associated with the return over $\left[2, d_{1}\right]$ while its association with the return over $\left[d_{1}, d_{2}\right]$ can be ambiguous.

\section{A. Nonparametric Tests of the Self-Attribution Hypothesis}

To test the self-attribution hypothesis, we use the sign of earnings surprise to gauge the outcome of institutions' pre-announcement demand. We also use the post-announcement CAR to infer institutions' reaction to earnings announcements since we have confirmed there is a positive contemporaneous relationship between CAR and CAID. Thus, we first sort stocks into quintiles based on $\operatorname{CAID}_{[-40,-1]}$. Within each of these quintiles, stocks are further sorted into quintiles according to SUE. ${ }^{20}$ Table 5 focuses on post-announcement CARs of the four out of these 25 subsamples. They are the two subsamples of stocks with the highest (positive) and lowest (negative) SUEs within quintiles of largest (positive) and smallest (negative) $\operatorname{CAID}_{[-40,-1]}$. As we can see from the first two columns in the upper panel of the table, for stocks with strong pre-

\footnotetext{
${ }^{20}$ Both CAID and SUE vary from negative to positive. Quintiles are arranged from 1 to 5 as their CAID or SUE measure increases from the smallest (negative) to the largest (positive).
} 
announcement institutional buys and positive earnings news, i.e., $Q\left(\operatorname{CAID}_{[-40,-1]}\right)=5$ and $Q(\mathrm{SUE})=5$, the average $\operatorname{CAR}_{[2,60]}$ is $-0.57 \%$ and insignificant, while the average $\mathrm{CAR}_{[61,120]}$ is $-1.38 \%$ and significant at the $1 \%$ level. It indicates that the correction of mispricing is delayed to the later period of $[61,120]$ when positive earnings news confirms strong pre-announcement institutional buys. Similarly, the subsample of $Q\left(\operatorname{CAID}_{[-40,-1]}\right)=1$ and $Q(\operatorname{SUE})=1$ yields an insignificant average $\operatorname{CAR}_{[2,60]}$ of $0.60 \%$ and a significant $\operatorname{CAR}_{[61,120]}$ of $1.25 \%$, showing that the correction of mispricing is delayed when strong pre-announcement institutional sells are favored by negative earnings news.

\section{INSERT TABLE 5 HERE}

In contrast, when earnings news disconfirms institutions' investment outcomes, we observe a strong correction of mispricing in the earlier period of $[2,60]$ but a negligible return drift in the later period of $[61,120]$. In particular, stocks in $Q\left(\operatorname{CAID}_{[-40,-1]}\right)=5$ and $Q(\mathrm{SUE})=1$ on average show a significant $\mathrm{CAR}_{[2,60]}$ of $-2.58 \%$ but an insignificant $\mathrm{CAR}_{[61,120]}$ of $-0.46 \%$. Likewise, the subsample of $Q\left(\operatorname{CAID}_{[-40,-1]}\right)=1$ and $Q(\mathrm{SUE})=5$ has a significant average $\mathrm{CAR}_{[2,60]}$ of $1.19 \%$ but an insignificant average $\mathrm{CAR}_{[61,120]}$ of $0.52 \%$. Therefore, stock prices revert back to the fundamentals in the earlier period of $[2,60]$ in the case of disconfirming earnings news. The third column of the panel reports the average CAR difference between the earlier and later periods. Among 3 out of the 4 subsamples considered, CARs over the earlier and later periods differ significantly, confirming the contrasting patterns of mispricing correction.

Since the later announcement period of $[61,120]$ covers next earnings announcements, it is possible that $\operatorname{CAR}_{[61,120]}$ is driven by next earnings surprises instead of the delayed correction of mispricing by institutions. To address this concern, the fourth column in the upper panel reports the average SUE of next earnings announcements ( $\left.S_{U E} E_{\text {next }}\right)$. In the two subsamples with 
confirming news, $\mathrm{CAR}_{[61,120]}$ is significant but its direction is opposite to that of $\mathrm{SUE}_{\text {next }}$, which suggests that next earnings announcements do not drive $\mathrm{CAR}_{[61,120]}$. On the other hand, $\mathrm{CAR}_{[61,120]}$ is insignificant and in the same direction of $\mathrm{SUE}_{\text {next }}$ for the stocks in the two subsamples with disconfirming news.

To further mitigate the contamination of $\mathrm{SUE}_{\text {next }}$ on post-announcement CARs, we consider shorter earlier and later post-announcement periods, $[2,10]$ vs. $[11,20],[2,20]$ vs. $[21,40]$, and $[2,30]$ vs. $[31,60]$, to avoid the overlap. For the stocks with strong preannouncement institutional buys and followed by positive earnings surprises, i.e., stocks in $Q\left(\operatorname{CAID}_{[-40,-1]}\right)=5$ and $Q(\mathrm{SUE})=5$, institutions tend to continue mispricing the stocks in the 2 weeks after earnings announcements, as evidenced by the significantly positive average $\operatorname{CAR}_{[2,10]}$ of $0.52 \%$. This mispricing is then eased and correction starts, as the average $\operatorname{CAR}_{[11,20]}$ is insignificant and the average $\mathrm{CAR}_{[21,40]}$ and $\mathrm{CAR}_{[31,60]}$ are significantly negative. For the stocks in $Q\left(\operatorname{CAID}_{[-40,-1]}\right)=5$ and $Q(\mathrm{SUE})=1$, the average CAR is significantly negative over the earlier post-announcement periods of $[2,10],[2,20]$, and $[2,30]$, which suggests that institutions start to correct the mispricing shortly after receiving disconfirming earnings news.

In sum, the results documented in Table 5 are consistent with the stock price paths illustrated by the two plots in Graphs C and D of Figure 1. As predicted by the self-attribution hypothesis, confirming earnings news makes institutions more overly confident, leading to a delay in correcting mispricing, while disconfirming earnings news urges institutions to correct their mistakes sooner. 
Following the placebo approach in Subsection III.B, we replicate the analysis in Table 5 for actual and pseudo earnings announcements based on a pre-announcement period of 20 days. $^{21}$ To avoid the overlap of post-announcement periods with next announcements, we restrict our analysis to the earlier and later post-announcement periods of $[2,10]$ and $[11,20]$. We use announcement $\mathrm{CAR}$, i.e., $\mathrm{CAR}_{[0,1]}$, to proxy for earnings surprise so that earnings surprises for pseudo earnings announcements are measurable. As shown in the fourth and fifth columns of Table 6 , there is no continuation but correction of mispricing after confirming pseudo earnings news, probably due to price pressure. For disconfirming pseudo earnings announcements, we do not observe mispricing correction in the earlier post-announcement period. These observations are in sharp contrast to the return patterns shown in the first two columns of Table 6 , where earnings announcements are actual. The sixth column reports the average difference of the postpseudo announcement CARs between the earlier and later periods, which is largely insignificant with the smallest $p$-value being 0.0927 among the 4 subsamples. The last two columns compare the post-announcement CARs between the actual and pseudo announcements, confirming the majority of these differences are significant. Collectively, our placebo tests here demonstrate that earnings announcements provide an essential setting for testing self-attribution bias. Furthermore, the observations of institutional trading and market behavior around earnings announcements are not some random coincidences.

\section{INSERT TABLE 6 HERE}

\section{B. Regression Tests of the Self-Attribution Hypothesis}

To further test the self-attribution hypothesis, we regress $\operatorname{CAR}_{\left[t_{1}, t_{2}\right]}$ on $\operatorname{CAID}_{[-40,-1]}$, taking the directions of SUE and $\operatorname{CAID}_{[-40,-1]}$ into account:

\footnotetext{
${ }^{21}$ Table A6 in the Supplementary Material considers a pre-announcement period of 10 days and reports similar results.
} 


$$
\begin{aligned}
\operatorname{CAR}_{\left[t_{1}, t_{2}\right]}= & \beta_{0}+\beta_{1} \operatorname{CAID}_{[-40,-1]} \times \boldsymbol{I}\left(\operatorname{SUE} \times \operatorname{CAID}_{[-40,-1]}>0\right)+\beta_{2} \operatorname{CAID}_{[-40,-1]} \times \\
& \boldsymbol{I}\left(\operatorname{SUE} \times \operatorname{CAID}_{[-40,-1]} \leq 0\right)+\beta_{3} \operatorname{CAR}_{[-40,-1]}+\sum_{i=1}^{12} \gamma_{i} \operatorname{CV}_{i}+\varepsilon,
\end{aligned}
$$

where $\boldsymbol{I}(x>0)$ is an indicator function taking the value of 1 if the condition $x>0$ is satisfied and 0 otherwise. The first two columns in Panel A of Table 7 show that $\beta_{1}$ is -0.0004 and -0.0006 for the regressions of $\operatorname{CAR}_{[2,60]}$ and $\mathrm{CAR}_{[61,120]}$, respectively, and both are significant at the $5 \%$ level. This implies the later period of $[61,120]$ experiences a more substantial correction of mispricing than the earlier period of $[2,60]$, supporting the argument that confirming earnings news exacerbate institutions' overconfidence and delay their actions of correcting mispricing. On the other hand, $\beta_{2}$ is -0.0009 and significant at the $1 \%$ level for the regression of $\mathrm{CAR}_{[2,60]}$ and it turns out to be an insignificant -0.0001 for $\operatorname{CAR}_{[61,120]}$. Therefore, the correction of mispricing occurs only in the earlier period of $[2,60]$ and there is no observable delay if disconfirming earnings news arrives at the market. The delay effect can be further illustrated by the comparison between $\beta_{1}$ and $\beta_{2}$ in the same period: the former has a smaller magnitude and t-statistic than the latter in the earlier period of $[2,60]$ while the opposite is true in the later period of $[61,120]$. Thus both regression results in the first two columns support the self-attribution hypothesis.

\section{INSERT TABLE 7 HERE}

To ensure the robustness of our tests for the self-attribution hypothesis and to avoid the contamination of next earnings surprises, we experiment with different pairs of earlier and later periods that end before the next earnings announcements. They generate qualitatively similar results. For instance, the third and fourth columns of Panel A document even stronger results for the pair of $[2,10]$ vs. $[11,20]$. In particular, $\beta_{1}$ in the third column is 0.00003 and insignificant and it changes to a significant -0.0001 in the fourth column. This means there is no material mispricing correction during $[2,10]$ after confirming earnings news arrives; however, substantial 
corrections occur after day 10. A comparison of the first two columns with the third and fourth columns in Panel A suggests that confirming earnings news can trigger further mispricing in the post-announcement period, as predicted by the self-attribution hypothesis. Such momentum, nevertheless, is short-lived and eventually reversed as more public information gradually draws prices back to the fundamentals as illustrated by Graphs C and D of Figure 1. The earlier and later post-announcement periods of $[2,20]$ vs. $[21,40]$ and $[2,30]$ vs. $[31,60]$ in the last four columns in the panel show consistent results.

While regression equation (6) takes the direction of an earnings announcement into account, equation (7) below considers not only its direction but also its magnitude:

$$
\begin{aligned}
\operatorname{CAR}_{\left[t_{1}, t_{2}\right]}= & \beta_{0}+\beta_{1} \operatorname{CAID}_{[-40,-1]} \times \mathbf{I}\left(\operatorname{SUE} \times \operatorname{CAID}_{[-40,-1]}>0\right) \times|\mathrm{SUE}| \\
& +\beta_{2} \operatorname{CAID}_{[-40,-1]} \times \mathbf{I}\left(\operatorname{SUE} \times \operatorname{CAID}_{[-40,-1]} \leq 0\right) \times|\mathrm{SUE}| \\
& +\beta_{3} \operatorname{CAR}_{[-40,-1]}+\beta_{4}|\mathrm{SUE}|+\sum_{i=1}^{12} \gamma_{i} \mathrm{CV}_{i}+\varepsilon
\end{aligned}
$$

The regression results in Panel B of Table 7 show that the $\beta_{1}$ estimate is $-0.00002(-0.0001)$ and insignificantly (significantly) different from 0 when $\operatorname{CAR}_{[2,60]}\left(\operatorname{CAR}_{[61,120]}\right)$ is the dependent variable. Since the regression coefficient of $\operatorname{CAID}_{[-40,-1]}$ is $\beta_{1}|\mathrm{SUE}|$ for stocks with confirming earnings news, we find institutions are likely to continue to misprice the stocks in period $[2,60]$ and mispricing correction occurs in the later period of $[61,120]$ if they observe an confirming surprise. Moreover, the magnitude of this delayed correction increases in $|\mathrm{SUE}|$. On the other hand, the estimated $\beta_{2}$ is $-0.0002(-0.00001)$ and significant (insignificant) for the regression on $\mathrm{CAR}_{[2,60]}\left(\mathrm{CAR}_{[61,120]}\right)$. This demonstrates that institutions are committed to mispricing correction in period $[2,60]$ but not so much in period $[61,120]$ upon receiving disconfirming earnings surprises. Their commitments are also positively related to |SUE|. Therefore, combining the regression results of $\mathrm{CAR}_{[2,60]}$ and $\mathrm{CAR}_{[61,120]}$, we find clear evidence of asymmetric 
correction of mispricing and its dependence on institutions' investment outcomes. ${ }^{22}$ Furthermore, if the confirming earnings surprise is greater, the delay phenomenon is stronger. We also consider other earlier and later post-announcement periods for regression equation (7) and our findings remain qualitatively similar and sometimes are even stronger.

While regression equations (6) and (7) examine the impact of direction and magnitude of earnings surprises on changes in institutions' confidence level, the accuracy or precision of such public signals may also matter. Although theory does not explicitly examine the effect of signal precision, ${ }^{23}$ one might expect institutional investors to more profoundly amend their confidence upon observing more accurate earnings signals. To study this effect, we adopt various proxies for signal precision but fail to find convincing evidence validating the role of signal precision in affecting institutions' confidence.

\section{Further Tests Based on Institutional Demand After Earnings Announcements}

So far, we have investigated the behavioral bias of institutional investors by testing the relationship between their pre-announcement CAID and subsequent CAR. To further consolidate our empirical findings, we examine CAIDs over various periods after earnings announcements. More specifically, we replace the dependent variable $\mathrm{CAR}_{\left[t_{1}, t_{2}\right]}$ in regression equations (6) and (7) with CAID $\left[t_{1}, t_{2}\right]$. The results are reported in Table $8 .{ }^{24}$ As can be seen from Panel A, for stocks with earnings news confirming pre-announcement CAID, the coefficient of $\operatorname{CAID}_{[-40,-1]}$ is

\footnotetext{
${ }^{22}$ Our results in Table 7 remain qualitatively similar if we control for next earnings surprises and/or $\mathrm{CAR}_{[2,60]}$ in the regression of $\mathrm{CAR}_{[61,120]}$. We also extend regression equation (7) to control for the interaction between $\mathrm{CAID}_{[-40,-1]}$ and news direction and obtain qualitatively similar results, which are reported in Table A7 in the Supplementary Material to economize the size of the paper.

${ }^{23}$ For instance, the model developed by Daniel et al. (1998) considers two types of public signals. The first type are discrete signals, i.e., either positive or negative, and the precision of the signal is irrelevant to investor confidence. The second type of public signals are normally distributed, and the higher is the precision of new confirming signal the less likely is the investors to revise their confidence upward.

${ }^{24} \mathrm{We}$ consolidate $\operatorname{CAID}_{[41,60]}$ and $\operatorname{CAID}_{[61,80]}$ to $\operatorname{CAID}_{[41,80]}$, and $\operatorname{CAID}_{[81,100]}$ and $\operatorname{CAID}_{[101,120]}$ to $\operatorname{CAID}_{[81,120]}$ in Table 8. Table A10 in the Supplementary Material reports the results without the consolidation and uses various preannouncement periods.
} 
0.0313 and significant at the $1 \%$ level in the regression of $\operatorname{CAID}_{[2,20]}$. It turns out to be -0.0482 and significant at the $1 \%$ level in the regression of $\operatorname{CAID}_{[21,40]}$, and continues to be significantly negative for the regressions of CAIDs over later subperiods. This demonstrates that institutions continue their pre-announcement trading directions in the first calendar month after earnings news confirms their pre-announcement trading decisions but later on they change their trading directions. For stocks with disconfirming earnings news, the coefficient of $\operatorname{CAID}_{[-40,-1]}$ is -0.0196 and significant at the $1 \%$ level for the regression of $\operatorname{CAID}_{[2,20]}$ and remains significantly negative over later subperiods. This indicates institutions start their correction of mispricing shortly after disconfirming earnings announcements. The negative relationship between pre-announcement CAID and the CAID of earlier (later) post-announcement period is stronger (weaker) for stocks with disconfirming earnings news than confirming news, which is consistent with asymmetric shifts in institutions' confidence level.

\section{INSERT TABLE 8 HERE}

Panel B of Table 8 reports the regression results after taking the magnitude of earnings surprise into account. A greater positive (negative) surprise indicates a better investment outcome if institutions buy (sell) prior to the announcement, and institutions are expected to be more overly confident if they are subject to self-attribution bias. This is the case here since the regression coefficient of $\operatorname{CAID}_{[-40,-1]} \times I\left(\operatorname{SUE} \times \operatorname{CAID}_{[-40,-1]}>0\right) \times|\mathrm{SUE}|$ is significantly positive for the regression of $\mathrm{CAID}_{[2,20]}$ and turns out to be significantly negative for the regressions of CAIDs in the later periods. In addition, for the regressions of CAIDs in later periods, the coefficient of $\operatorname{CAID}_{[-40,-1]} \times I\left(\operatorname{SUE} \times \operatorname{CAID}_{[-40,-1]}>0\right) \times|\mathrm{SUE}|$ is more negative than the corresponding coefficient of $\operatorname{CAID}_{[-40,-1]} \times I\left(\operatorname{SUE} \times \operatorname{CAID}_{[-40,-1]} \leq 0\right) \times|\mathrm{SUE}|$. Therefore, the asymmetric patterns in the regression coefficients of $\operatorname{CAID}_{[-40,-1]}$ increase with $|\mathrm{SUE}|$. 
Since ANcerno data provide client codes for the sample period until December 2010, we further examine the behavioral bias at the level of individual ANcerno clients. The demand of an ANcerno client is characterized by the daily imbalance as shown here:

$$
\operatorname{IIM}_{k, i, t}=\frac{\text { BUYVOLUME }_{k, i, t}-\operatorname{SELLVOLUME}_{k, i, t}}{\text { BUYVOLUME }_{k, i, t}+\operatorname{SELLVOLUME}_{k, i, t}},
$$

where BUYVOLUME $k, i, t\left(\operatorname{SELLVOLUME}_{k, i, t}\right)$ is the number of shares purchased (sold) by ANcerno institution $k$ for stock $i$ on day $t$. Then the abnormal demand is proxied by the standardized volume imbalance:

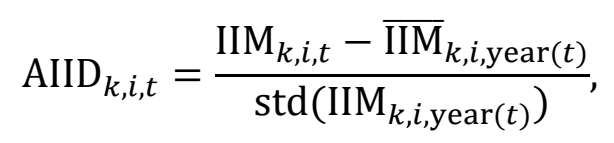

where year( $(t)$ denotes the year of which day $t$ belongs to and $\overline{\operatorname{IIM}}_{k, i, \text { year }(t)}$ and $\operatorname{std}\left(\operatorname{IIM}_{k, i, y e a r(t)}\right)$ are sample mean and standard deviation of $\operatorname{IIM}_{k, i, t}$ over year $(t)$. Consequently, cumulative abnormal individual institutional demand over period $\left[t_{1}, t_{2}\right]$ is $\operatorname{CAIID}_{i,\left[t_{1}, t_{2}\right]}=\sum_{t=t_{1}}^{t_{2}} \operatorname{AIID}_{i, t}$.

In Panel A of Table 9, we divide all client-announcement observations into two subsamples, one with confirming news and the other with disconfirming news, and report the percentage of individual institutions continuing their pre-announcement trading directions over the subperiods after earnings announcements. As can be seen from the first column, 61.02\% (10.11\%) of individual institutions continue their pre-announcement trading directions over the period of $[2,20]$ after receiving confirming (disconfirming) news. When moving to the later postannouncement periods, the percentage of institutions continuing their pre-announcement trading directions reduces gradually for the subsample with confirming news and turns out to be less than $50 \%$, consistent with delayed correction of mispricing. For the subsample with disconfirming news, the percentage of institutions trading in the opposite directions of their pre-announcement trading remains high over all subperiods after earnings announcements. 


\section{INSERT TABLE 9 HERE}

To further examine the probability of individual institutions continuing their preannouncement trading directions in the post-announcement period of $\left[t_{1}, t_{2}\right]$, we run the following two Probit regressions:

$$
\begin{aligned}
& \operatorname{Pr}\left(\mathrm{CO}_{\left[t_{1}, t_{2}\right]}\right)=\Phi\left(\beta_{0}+\beta_{1} I\left(\operatorname{SUE} \times \operatorname{CAIID}_{[-40,-1]}>0\right)+\beta_{2} \operatorname{CAIID}_{[-40,-1]}\right. \\
& \left.+\beta_{3} \mathrm{CAR}_{[-40,-1]}+\sum_{i=1}^{12} \gamma_{i} \mathrm{CV}_{i}+\varepsilon\right) \text {, } \\
& \operatorname{Pr}\left(\mathrm{CO}_{\left[t_{1}, t_{2}\right]}\right)=\Phi\left(\beta_{0}+\left(\beta_{1}+\beta_{2}|\operatorname{SUE}|\right) \boldsymbol{I}\left(\operatorname{SUE} \times \operatorname{CAIID}_{[-40,-1]}>0\right)+\right. \\
& \left.+\beta_{3} \operatorname{CAIID}_{[-40,-1]}+\beta_{4} \operatorname{CAR}_{[-40,-1]}+\beta_{5}|\mathrm{SUE}|+\sum_{i=1}^{12} \gamma_{i} \mathrm{CV}_{i}+\varepsilon\right) \text {, }
\end{aligned}
$$

where dummy variable $\mathrm{CO}_{\left[t_{1}, t_{2}\right]}$ takes the value of 1 if $\operatorname{CAIID}_{\left[t_{1}, t_{2}\right]} \times \operatorname{CAIID}_{[-40,-1]}>0$ and 0 otherwise. $\operatorname{Pr}\left(\mathrm{CO}_{\left[t_{1}, t_{2}\right]}\right)$ denotes the probability of $\mathrm{CO}_{\left[t_{1}, t_{2}\right]}$ being 1 and $\Phi(\cdot)$ is the cumulative distribution function of the standard normal distribution. We focus on the economic significance of our results and present the marginal effects obtained from the Probit models in Panel B of Table 9. We observe from regression equation (10) that individual institutions are more likely to continue their pre-announcement trading directions after confirming earnings announcements. For instance, the probability of continuation increases by $53.94 \%$ over the period of $[2,20]$, but this figure gradually declines in later periods. The results in the lower segment of Panel B indicate that the likelihood of trading continuation is positively related to the magnitude of earnings surprise. Collectively, our trading tests confirm that institutions' confidence is outcome-dependent and they become more overly confident if their trading decisions are confirmed by more surprising earnings news.

\section{The PEAD Anomaly}

Our tests of the self-attribution hypothesis reveal that the return pattern of a stock after its earnings announcements largely depends on institutional investors' reaction to earnings news. Thus, a natural question to ask is whether institutions' overconfidence, self-attribution bias in 
particular, can contribute to the PEAD anomaly. Before answering this question, we first confirm the existence of the PEAD anomaly by testing the following model:

$$
\operatorname{CAR}_{\left[t_{1}, t_{2}\right]}=\beta_{0}+\beta_{1} \operatorname{SUE}+\beta_{2} \operatorname{CAR}_{[-40,-1]}+\sum_{i=1}^{12} \gamma_{i} \mathrm{CV}_{i}+\varepsilon
$$

The literature on the PEAD anomaly usually adopts a period of 60 days after an earnings announcement as the post-announcement period (see, e.g., Bernard and Thomas (1989)). Thus, the period of $[2,60]$ in Table 10 is the focus of our PEAD analysis but we also include period $[61,120]$ to investigate the effect of delayed correction of mispricing by institutions. The first column displays a significantly positive relationship between SUE and $\operatorname{CAR}_{[2,60]}$. Thus, CAR drifts in the same direction of SUE in the period of day 2 to day 60 , indicating the existence of the PEAD anomaly. However, this drift is partially reversed in the later period of day 61 to day 120 as the third column documents a negative relationship between SUE and $\operatorname{CAR}_{[61,120]}$. A similar reversal has also been observed by Milian (2015).

\section{INSERT TABLE 10 HERE}

Because institutions' trading and mispricing correction in the post-announcement period depend on the outcome of their pre-announcement investment, we augment equation (12) to examine the impact of earnings surprise conditional on whether earnings announcements confirm or disconfirm pre-announcement institutional demand:

$$
\begin{aligned}
\operatorname{CAR}_{\left[t_{1}, t_{2}\right]}= & \beta_{0}+\beta_{1} \operatorname{SUE} \times I\left(\operatorname{SUE} \times \operatorname{CAID}_{[-40,-1]}>0\right) \\
& +\beta_{2} \operatorname{SUE} \times \boldsymbol{I}\left(\operatorname{SUE} \times \operatorname{CAID}_{[-40,-1]} \leq 0\right)+\beta_{3} \operatorname{CAR}_{[-40,-1]}+\sum_{i=1}^{12} \gamma_{i} \mathrm{CV}_{i}+\varepsilon
\end{aligned}
$$

The second column in Table 10 shows that the predictive effects of SUE on $\mathrm{CAR}_{[2,60]}$ exhibit a profound difference between stocks with confirming and disconfirming earnings news. More specifically, the positive relationship between SUE and $\mathrm{CAR}_{[2,60]}$ remains significant for stocks with disconfirming earnings news, while the relationship is insignificant for stocks with 
confirming earnings news. This suggests that institutional investors tend to correct mispricing in a timely manner when earnings news disconfirms their pre-announcement trading, and therefore CAR over period $[2,60]$ drifts in the direction of earnings news. Nevertheless, institutional trading after receiving confirming earnings news does not trigger the anomaly. Combining both types of earnings news together, we observe a standard PEAD anomaly as shown in the first column of Table 10. Moving to the later period of day 61 to day 120, the fourth column documents a significantly (insignificantly) negative relationship between SUE and $\mathrm{CAR}_{[61,120]}$ for stocks with confirming (disconfirming) earnings news. This suggests that institutions continue their delayed correction of mispricing in this later period upon receiving confirming earnings news; however, there is no tangible CAR drift if news is disconfirming. Averaging over the two types of earnings news leads to the PEAD reversal shown in the third column of Table 10.

To further understand how institutions' self-attribution bias is linked to the PEAD anomaly over the period of day 2 to day 60 , we consider two subperiods of $[2,30]$ and $[31,60]$ and replicate regression questions (12) and (13). The predictive effect of SUE on $\mathrm{CAR}_{[2,30]}$ remains strong for stocks with disconfirming earnings news, consistent with institutions starting to correct the stock mispricing shortly after the earnings announcements. For stocks with confirming news, SUE becomes a significant return predictor over the day 2 to day 30 period. It demonstrates that institutions tend to continue their mispricing shortly after earnings announcements when their preannouncement trades are confirmed by earnings news, and such reinforced confidence also contributes to the PEAD anomaly as predicted by Daniel et al. (1998).

\section{Robustness Checks}

The relationship between pre-announcement CAID and post-announcement CAR can be sensitive to the choice of pre-announcement and post-announcement time windows. As reported 
earlier, we have adopted various windows for these periods and find qualitatively similar results. For brevity, most of them are tabulated in the Supplementary Material. On top of these considerations, we perform various further tests to examine the robustness of our findings.

\section{A. Alternative Measure of Institutional Demand}

Motivated by the theoretical herding literature, Dasgupta et al. (2011) propose institutional trade persistence as a proxy for institutional trading. Following this, we consider an alternative measure of institutional demand, namely, the Ratio of Institutional Trading (RIT):

$$
\operatorname{RIT}_{i, k}=\frac{\text { BUYDAYS }_{i, k}-\text { SELLDAYS }_{i, k}}{\text { BUYDAYS }_{i, k}+\operatorname{SELLDAYS~}_{i, k}}
$$

where BUYDAYS ${ }_{i, k}$ and SELLDAYS ${ }_{i, k}$ are the total numbers of days that stock $i$ is net purchased and sold, respectively, by ANcerno institutions during period $k$. Pre-announcement abnormal

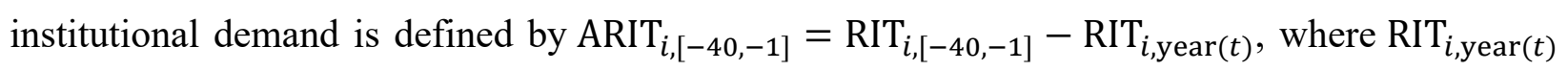
is the institutional trading ratio for the year of which the announcement date belongs to. Panel A of Table A14 in the Supplementary Material documents the results of the regression analysis of various CARs as specified in equation (3) but using $\operatorname{ARIT}_{[-40,-1]}$ instead of $\operatorname{CAID}_{[-40,-1]}$ as the key explanatory variable. A significantly negative relationship exists between $\operatorname{ARIT}_{[-40,-1]}$ and subsequent return, which is consistent with the overconfidence findings using $\operatorname{CAID}_{[-40,-1]}$. To test for institutions' outcome-dependent confidence, we rerun regression equations (6) and (7) but use $\operatorname{ARIT}_{[-40,-1]}$ instead of $\operatorname{CAID}_{[-40,-1]}$ as the key explanatory variable and present the results in Panels B and C of Table A14. They reveal findings similar to Table 7 and support the selfattribution hypothesis. 


\section{B. Alternative Measure of Abnormal Return}

We consider an alternative measure of abnormal return by matching a sample stock with the stocks of similar size, book-to-market $(\mathrm{B} / \mathrm{M})$ ratio and momentum that also announce earnings in the same calendar quarter. Each quarter, 125 benchmark portfolios are constructed and abnormal return is then calculated as raw stock return minus the average return of the benchmark that the stock falls in. Table A15 in the Supplementary Material indicates that support for the overconfident institutions and their self-attribution bias is robust to the alternative CAR measure.

\section{Other Robustness Checks}

Recent studies reveal that past volume and return can predict return over earnings announcement period (Akbas (2016)). Therefore, we use dummy variables of unusually low volume and the prior 12-month return to control for such return predictability in unreported regression analysis. Although ANcerno clients are largely pension and mutual funds, there are a small number of hedge funds. To avoid institution heterogeneity, we exclude hedge funds when calculating CAID and report the main results in Supplementary Material, Table A16. ${ }^{25}$ Our analysis requires pre-announcement (post-announcement) periods up to 40 (120) days. It is likely that some institutions become ANcerno clients or stop being their clients during our evaluation periods. To address the issue of sample variation, we also estimate CAID based on ANcerno institutions which have their first (last) report date before (after) the start (end) of preannouncement (post-announcement) period, and report the results of our main analysis in Supplementary Material, Table A17. Our findings of overconfident institutions and their selfattribution bias do not have qualitative changes in these robustness tests.

\footnotetext{
${ }^{25}$ We thank Russell Jame for making the list of ANcerno client-manager pairs classified as hedge funds available on his personal website. In our ANcerno data, client codes are not provided after 2010. Therefore, we consider the sample period from 2000 to 2010 in the analysis which requires the information on client codes, including Table 9 in the paper and Tables A11, A16, and A17 in the Supplementary Material.
} 


\section{Concluding Remarks}

This paper examines the association between the behavioral bias of institutional investors and market mispricing around earnings announcements, which is exceptionally interesting because mispricing correction is often particularly strong when earnings news is released. We provide evidence of pre-announcement abnormal institutional demand negatively predicting subsequent abnormal returns, and show that overconfidence of institutions rather than institutional trading's price pressure drives stock prices to deviate from the fundamentals before earnings announcements. We also demonstrate that the negative relationship is stronger for stocks being more difficult to value and having higher information asymmetry. This offers evidence that institutional investors tend to be more overly confident in these situations.

By conditioning on earnings surprise, we examine institutions' outcome-dependent confidence arising from biased self-attribution. Confirming earnings news is likely to exacerbate the overconfidence of institutional investors, and in turn lead them to be even more biased in the period immediately after earnings announcements and delay mispricing correction. However, disconfirming earnings news does not have such effects and consequently the correction occurs sooner. These asymmetric changes in investors' confidence and the resulting asymmetric mispricing correction after earnings announcements contribute to the PEAD phenomenon. 


\section{References}

Aboody, D., and B. Lev. "Information Asymmetry, R\&D, and Insider Gains." Journal of Finance, 55 (2000), 2747-2766.

Akbas, F. "The Calm before the Storm." Journal of Finance, 71 (2016), 225-266.

Amihud, Y. "Illiquidity and Stock Returns: Cross-Section and Time-Series Effects." Journal of Financial Markets, 5 (2002), 31-56.

Anand, A.; P. Irvine; A. Puckett; and K. Venkataraman. "Performance of Institutional Trading Desks: An Analysis of Persistence in Trading Costs." Review of Financial Studies, 25 (2012), 557-598.

Baker, M.; L. Litov; J. A. Wachter; and J. Wurgler. "Can Mutual Fund Managers Pick Stocks? Evidence from Their Trades Prior to Earnings Announcements." Journal of Financial and Quantitative Analysis, 45 (2010), 1111-1131.

Ball, R., and P. Brown. "An Empirical Evaluation of Accounting Income Numbers." Journal of Accounting Research, 6 (1968), 159-178.

Banerjee, S. "Learning from Prices and the Dispersion in Beliefs." Review of Financial Studies, 23 (2011), 3025-3068.

Bernard, V.; J. Thomas; and J. Wahlen. "Accounting-Based Stock Price Anomalies: Separating Market Inefficiencies from Risk.” Contemporary Accounting Research, 14 (1997), 89-136.

Bernard, V. L., and J. K. Thomas. "Post-Earnings-Announcement Drift: Delayed Price Response or Risk Premium?” Journal of Accounting Research, 27 (1989), 1-36.

Bhattacharya, N.; H. Desai; and K. Venkataraman. "Does Earnings Quality Affect Information Asymmetry? Evidence from Trading Costs." Review of Financial Studies, 23 (2013), 30253068.

Brown, N. C.; K. D. Wei; and R. Wermers. "Analyst Recommendations, Mutual Fund Herding, and Overreaction in Stock Prices." Management Science, 60 (2014), 1-20.

Brown, S., and S. A. Hillegeist. "How Disclosure Quality Affects the Level of Information Asymmetry." Review of Accounting Studies, 12 (2007), 443-477.

Brown, S.; S. A. Hillegeist; and K. Lo. "The Effect of Earnings Surprises on Information Asymmetry." Journal of Accounting and Economics, 47 (2009), 208-225.

Busse, J. A.; T. C. Green; and N. Jegadeesh. "Buy-Side Trades and Sell-Side Recommendations: Interactions and Information Content." Journal of Financial Markets, 15 (2012), 207-232.

Chan, L. K. C., and J. Lakonishok. "Institutional Equity Trading Costs: NYSE versus Nasdaq." Journal of Finance, 52 (1997), 713-735.

Daniel, K., and D. Hirshleifer. "Overconfident Investors, Predictable Returns, and Excessive Trading." Journal of Economic Perspectives, 29 (2015), 61-87.

Daniel, K.; D. Hirshleifer; and A. Subrahmanyam. "Investor Psychology and Security Market Under- and Overreactions.” Journal of Finance, 53 (1998), 1839-1885.

Dasgupta, A.; A. Prat; and M. Verardo. "Institutional Trade Persistence and Long-Term Equity Returns." Journal of Finance, 66 (2011), 635-653.

Easley, D.; N. K. Kiefer; and M. O'Hara. "One Day in the Life of a Very Common Stock." Review of Financial Studies, 10 (1997), 805-835.

Edelen, R. M.; O. S. Ince; and G. B. Kadlec. "Institutional Investors and Stock Return Anomalies." Journal of Financial Economics, 119 (2016), 472-488.

Edelen, R. M., and J. B. Warner. "Aggregate Price Effects of Institutional Trading: A Study of Mutual Fund Flow and Market Returns.” Journal of Financial Economics, 59 (2001), 195-220. 
Einhorn, H. J. "Overconfidence in Judgement." New Directions for Methodology of Social and Behavioral Science, 4 (1980), 1-16.

Fama, E. F. "Market Efficiency, Long-Term Returns, and Behavioral Finance." Journal of Financial Economics, 49 (1998), 283-306.

Fernandes, N., and M. A. Ferreira. "Does International Cross-Listing Improve the Information Environment." Journal of Financial Economics, 88 (2008), 216-244.

Ferreira, M. A., and P. A. Laux. "Corporate Governance, Idiosyncratic Risk, and Information Flow." Journal of Finance, 62 (2007), 951-989.

Gervais, S., and T. Odean. "Learning to Be Overconfident." Review of Financial Studies, 14 (2001), $1-17$.

Griffin, D., and A. Tversky. "The Weighing of Evidence and the Determinants of Confidence." Cognitive Psychology, 24 (1992), 411-435.

Griffin, J. M.; T. Shu; and S. Topaloglu. "Examining the Dark Side of Financial Markets: Do Institutions Trade on Information from Investment Bank Connections?" Review of Financial Studies, 25 (2012), 2155-2188.

Hirshleifer, D.; J. N. Myers; L. Myers; and S. H. Teoh. "Do Individual Investors Cause PostEarnings Announcement Drift? Direct Evidence from Personal Trades." The Accounting Review, 83 (2008), 1521-1550.

Jegadeesh, N. "Evidence of Predictable Behavior of Security Returns." Journal of Finance, 45 (1990), 881-898.

Jiang, H., and Z. Sun. "Dispersion in Beliefs among Active Mutual Funds and the Cross-Section of Stock Returns." Journal of Financial Economics, 114 (2014), 341-365.

Kaniel, R.; S. Liu; G. Saar; and S. Titman. "Individual Investor Trading and Return Patterns around Earnings Announcements." Journal of Finance, 67 (2012), 639-680.

Ke, B., and S. Ramalingegowda. "Do Institutional Investors Exploit the Post-Earnings Announcement Drift?" Journal of Accounting and Economics, 39 (2005), 25-53.

Keim, D. B., and A. Madhavan. "Anatomy of the Trading Process: Empirical Evidence on the Behavior of Institutional Traders." Journal of Financial Economics, 37 (1995), 371-398.

Keren, G. "On the Calibration of Probability Judgements: Some Critical Comments and Alternative Perspectives." Journal of Behavioral Decision Making, 10 (1997), 269-278.

Koehler, D. J.; L. Brenner; and D. Griffin. "The Calibration of Expert Judgment: Heuristics and Biases beyond the Laboratory." In Heuristics and Biases: The Psychology of Intuitive Judgement, T. Gilovich, D. Griffin, and D. Kahneman, eds. New York: Cambridge University Press (2002), 686-715.

Kumar, A. "Hard-to-Value Stocks, Behavioral Biases, and Informed Trading." Journal of Financial and Quantitative Analysis, 44 (2009), 1375-1401.

Langer, E. J., and J. Roth. "Heads I Win Tails It's Chance: The Illusion of Control as A Function of the Sequence of Outcomes in a Purely Chance Tasks." Journal of Personality and Social Psychology, 32 (1975), 951-955.

Milian, J. A. "Unsophisticated Arbitrageurs and Market Efficiency: Overreacting to A History of Underreaction?" Journal of Accounting Research, 53 (2015), 175-220.

Moeller, S. B.; F. P. Schlingemann; and R. M. Stulz. "How Do Diversity of Opinion and Information Asymmetry Affect Acquirer Returns?” The Review of Financial Studies, 20 (2007), 2047-2078.

Pástor, L., and V. Pietro. "Stock Valuation and Learning about Profitability." Journal of Finance, 58 (2003), 1749-1789. 
Puckett, A., and X. Yan. "The Interim Trading Skills of Institutional Investors." Journal of Finance, 66 (2011), 601-633.

Savor, P., and M. Wilson. "Earnings Announcements and Systematic Risk." Journal of Finance 71 (2016), 83-138.

Shleifer, A., and R. W. Vishny. "The Limits of Arbitrage.” Journal of Finance, 52 (1997), 35-55.

So, E., and S. Wang. "News-Driven Return Reversals: Liquidity Provision Ahead of Earnings Announcement." Journal of Financial Economics, 114 (2014), 20-35.

Statman, M.; S. Thorley; and K. Vorkink. "Investor Overconfidence and Trading Volume.” Review of Financial Studies, 19 (2006), 1531-1565.

Taylor, S. E., and J. D. Brown. "Illusion and Well-Being: A Social Psychological Perspective on Mental Health.” Psychological Bulletin, 103 (1988), 193-210.

Venter, J. H., and D. C. J. de Jongh. "Extending the EKOP Model to Estimate the Probability of Informed Trading." Studies in Economics and Econometrics, 30 (2006), 25-39.

Warther V. A. "Aggregate Mutual Fund Flows and Security Returns." Journal of Financial Economics, 39 (1995), 209-235. 


\section{FIGURE 1}

\section{Stock Price Paths around an Earnings Announcement when Institutinal Investors are Overconfident}

In Figure1, announcement day is denoted by 0 while $2<d_{1}<d_{2}$ are two time points after an announcement. Confirming (disconfirming) earnings news refers to an earnings surpise on the same (wrong) side of institutional investors' pre-announcement trades, i.e., a buy followed by a positive (negative) earnings surprise or a sell followed by a negative (positive) earnings surprise. The plot in Graph A (Graph B) illustrates that institutions are overconfident and their strong pre-announcement buy (sell) drives the stock price above (below) the fundamental. However, they correct the mispricing over period $\left[2, d_{1}\right]$ following the earnings announcement and the price reverts to the fundamental value. The plots in Graphs $\mathrm{C}$ and $\mathrm{D}$ detail the price paths by separating confirming and disconfirming earnings announcements. The correction of mispricing by institutional investors is delayed, if they are subject to overconfidence and self-attribution bias and receive a confirming earnings announcement. The delayed correction, reflected by a short continuation of price movement, leads to an ambiguous direction of return over [2, $\left.d_{1}\right]$ but a considerable correction over $\left(d_{1}, d_{2}\right]$. If the earnings news is disconfirming, institutions take action to correct the mispricing in a timely manner and they may complete the correction before day $d_{1}$.
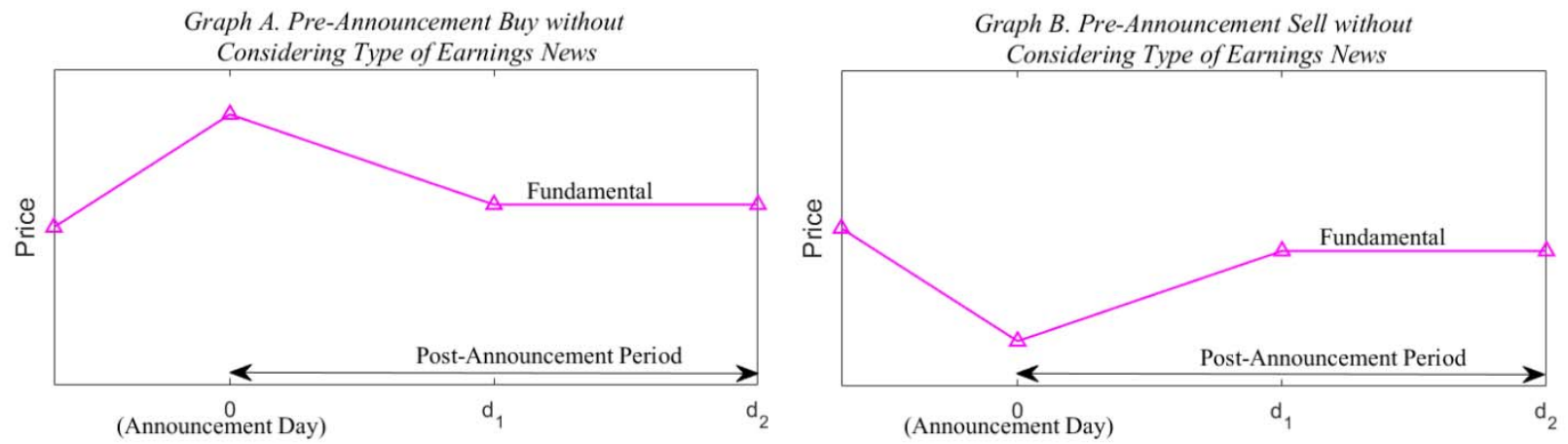

Graph C. Pre-Announcement Buy with Separation of Confirming and Disconfirming Earnings News
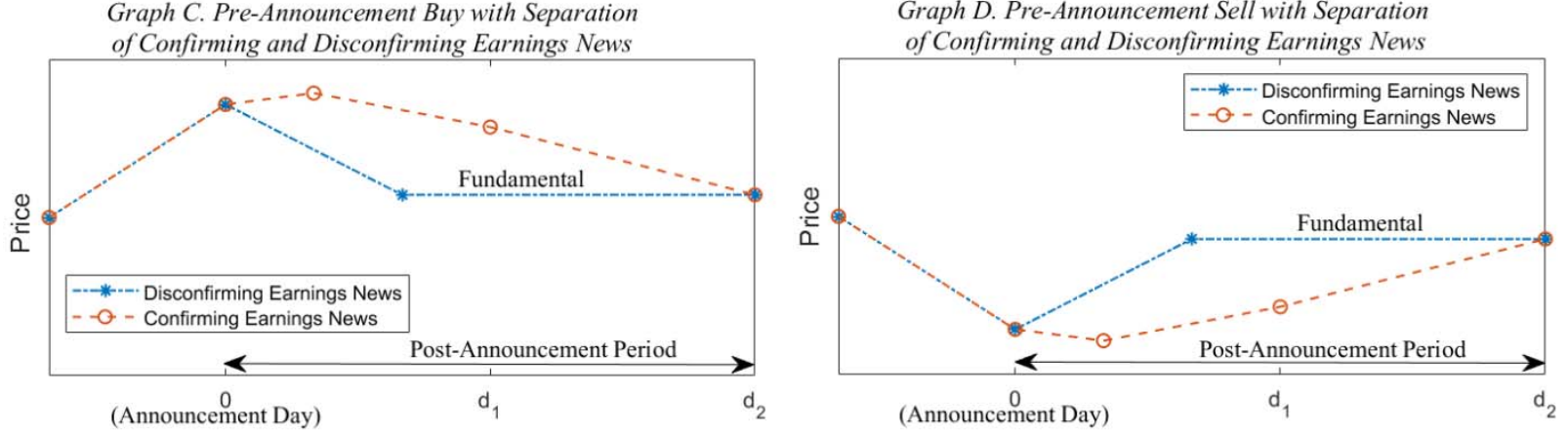


\section{TABLE 1}

\section{Summary Statistics of Sample Characteristics}

Table 1 presents the summary statistics of a sample of common stocks with quarterly earnings announcements from January 2000 to June 2013. For each announcement, $\mathrm{CAR}_{\left[t_{1}, t_{2}\right]}$ and $\mathrm{CAID}_{\left[t_{1}, t_{2}\right]}$ are the cumulative abnormal return and cumulative abnormal institutional demand, respectively, from day $t_{1}$ to day $t_{2}$, where event day is day 0 . Standardized unexpected earnings (SUE) is the difference between the actual earnings and the mean analyst forecast scaled by the standard deviation of the analyst forecasts, market capitalization (MKTCAP) the average daily market capitalization of a stock, stock price (PRICE) the average daily closing price, and illiquidity (ILLIQUIDITY) the average daily illiquidity ratio of Amihud (2002) multiplied by a factor of 1 million. Market beta (BETA) is obtained by regressing daily excess returns on Fama-French 3 factors and idiosyncratic volatility (IDIOV) is the standard deviation of regression residuals. Bid-ask spread (SPREAD) is the average daily closing bid-ask spread, institutional ownership (INST) the average fraction of shares outstanding held by institutions filing Form 13F, analyst coverage (ACOVERAGE) the average number of analysts following the stock on $\mathrm{I} / \mathrm{B} / \mathrm{E} / \mathrm{S}$, and book-to-market ratio (BM) the average book-tomarket ratio. Probability of information-based trading (PIN) is estimated based on the model of Easley et al. (1997). Firm age (AGE) is the number of years since the stock first appears in the CRSP database, dispersion in analyst forecasts (DISP) the standard deviation of analyst forecasts divided by the mean, turnover (TO) the average daily trading volume scaled by the number of shares outstanding, research and development intensity (R\&D) the firm's R\&D expenditures divided by its total assets, earnings quality (EARNINGSQ) the negative absolute value of industryadjusted operating accruals for the firm, cash flow volatility (CASHFLOWV) the volatility of the firm's operating cash flows scaled by its total assets during the past 5 years, and earnings volatility (EARNINGSV) the volatility of the firm's earnings before extraordinary items scaled by its total assets during the past 5 years. All these measures of stock characteristics are estimated using data in the year prior to an earnings announcement.

\begin{tabular}{lccccc} 
& Mean & SD & 25th & Median & 75th \\
\hline CAR $_{[-40,-1]}$ & $-0.01 \%$ & $17.96 \%$ & $-7.73 \%$ & $0.13 \%$ & $8.04 \%$ \\
CAR $_{[0,1]}$ & $0.02 \%$ & $8.94 \%$ & $-3.85 \%$ & $0.06 \%$ & $4.15 \%$ \\
CAR $_{[2,60]}$ & $-0.24 \%$ & $20.73 \%$ & $-9.47 \%$ & $-0.11 \%$ & $9.55 \%$ \\
CAID $_{[-40,-1]}$ & -0.085 & 11.514 & -7.513 & 0.000 & 7.469 \\
CAID $_{[0,1]}$ & -0.032 & 1.542 & -1.107 & 0.000 & 1.086 \\
CAID $_{[2,60]}$ & 0.142 & 14.470 & -9.211 & 0.000 & 9.559 \\
SUE & 0.982 & 3.792 & -0.483 & 0.737 & 2.402 \\
MKTCAP (in million $\$$ ) & 4609 & 12394 & 331 & 888 & 2853 \\
PRICE (in $\$)$ & 26.75 & 19.73 & 12.26 & 22.15 & 36.04 \\
ILLIQUIDITY & 0.080 & 0.634 & 0.001 & 0.004 & 0.019 \\
BETA & 1.045 & 0.498 & 0.738 & 1.006 & 1.317 \\
IDIOV & 0.027 & 0.015 & 0.016 & 0.023 & 0.034 \\
SPREAD & 0.006 & 0.008 & 0.001 & 0.002 & 0.007 \\
INST & 0.652 & 0.259 & 0.462 & 0.688 & 0.854 \\
ACOVERAGE & 8.616 & 6.333 & 3.833 & 6.667 & 11.750 \\
BM & 0.522 & 0.430 & 0.256 & 0.440 & 0.682 \\
PIN & 0.121 & 0.085 & 0.056 & 0.101 & 0.172 \\
AGE & 17.67 & 17.55 & 5.00 & 12.00 & 24.00 \\
DISP & 0.073 & 0.190 & 0.010 & 0.021 & 0.054 \\
TO & 0.010 & 0.008 & 0.004 & 0.007 & 0.012 \\
R\&D & 0.045 & 0.096 & 0.000 & 0.000 & 0.049 \\
EARNINGSQ & -0.057 & 0.078 & -0.070 & -0.033 & -0.127 \\
CASHFLOWV & 0.026 & 0.049 & 0.006 & 0.013 & 0.026 \\
EARNINGSV & 0.090 & 0.269 & 0.014 & 0.032 & 0.082 \\
\hline
\end{tabular}




\section{TABLE 2}

\section{Analysis of CARs Based on Pre-Announcement Institutional Demand}

Panel A of Table 2 presents a nonparametric analysis of CARs conditional on pre-announcement cumulative institutional demand. Daily abnormal institutional demand is measured by standardized trading volume imbalance of institutional investors. Sample stocks are sorted into quintiles based on pre-announcement cumulative abnormal institutional demand from day -40 to day $-1\left(\operatorname{CAID}_{[-40,-1]}\right)$. The panel reports the average cumulative abnormal returns over the period from day $t_{1}$ to day $t_{2}\left(\mathrm{CAR}_{\left[t_{1}, t_{2}\right]}\right)$ for each CAID quintile and the corresponding differences between Q5 and Q1, where Q5 (Q1) is the quintile of sample stocks strongly bought (sold) by institutions in the preannouncement period. Returns are reported in percentage terms. Panel B presents the regression analysis of CARs and adopts the regression specification:

$$
\operatorname{CAR}_{\left[t_{1}, t_{2}\right]}=\beta_{0}+\beta_{1} \operatorname{CAID}_{[-40,-1]}+\beta_{2} \operatorname{CAR}_{[-40,-1]}+\sum_{i=1}^{12} \gamma_{i} \operatorname{CV}_{i}+\varepsilon,
$$

where $\mathrm{CV}_{i}$ are control variables estimated in the year prior to the earnings announcements, including stock size, which is the logarithm of the average daily market capitalization, stock price, stock illiquidity, market beta, idiosyncratic volatility, bid-ask spread, institutional ownership, analyst coverage, book-to-market ratio, probability of informationbased trading, firm age, and dispersion in analyst forecasts of the stock. T-statistics are shown in parentheses. Symbols $* * *, * *$ and $*$ indicate significance at the $1 \%, 5 \%$, and 10\% levels, respectively. Standard errors are clustered by stock and calendar quarter (Petersen (2009)) and the 2-way cluster-robust t-statistics are reported for regression analysis.

\begin{tabular}{|c|c|c|c|c|c|c|}
\hline $\mathrm{CAID}_{[-40,-1]}$ & $\operatorname{CAR}_{[-40,-1]}$ & $\operatorname{CAR}_{[0,1]}$ & $\operatorname{CAR}_{[2,6]}$ & $\operatorname{CAR}_{[2,20]}$ & $\operatorname{CAR}_{[2,40]}$ & $\operatorname{CAR}_{[2,60]}$ \\
\hline \multicolumn{7}{|c|}{ Panel A. CARs Conditional on Pre-Announcement CAID } \\
\hline Q5 (Strong buy) & $\begin{array}{l}1.74 * * * \\
(13.06)\end{array}$ & $\begin{array}{c}-0.33 * * * \\
(-4.89)\end{array}$ & $\begin{array}{c}-0.26 * * * \\
(-4.96)\end{array}$ & $\begin{array}{c}-0.29 * * * \\
(-3.16)\end{array}$ & $\begin{array}{c}-0.87 * * * \\
(-6.48)\end{array}$ & $\begin{array}{c}-1.58 * * * \\
(-9.38)\end{array}$ \\
\hline Q4 & $\begin{array}{c}0.51 * * * \\
(4.56)\end{array}$ & $\begin{array}{c}-0.08 \\
(-1.34)\end{array}$ & $\begin{array}{l}-0.08 * \\
(-1.84)\end{array}$ & $\begin{array}{c}-0.02 \\
(-0.26)\end{array}$ & $\begin{array}{c}-0.11 \\
(-0.966)\end{array}$ & $\begin{array}{c}-0.31 * * \\
(-2.30)\end{array}$ \\
\hline Q3 & $\begin{array}{c}-0.69 * * * \\
(-3.73)\end{array}$ & $\begin{array}{c}-0.02 \\
(-0.26)\end{array}$ & $\begin{array}{c}-0.06 \\
(-0.81)\end{array}$ & $\begin{array}{l}0.03 \\
(0.24)\end{array}$ & $\begin{array}{c}-0.36 * * \\
(-2.01)\end{array}$ & $\begin{array}{c}-0.99 * * * \\
(-4.53)\end{array}$ \\
\hline Q2 & $\begin{array}{c}-0.32 * * \\
(-2.28)\end{array}$ & $\begin{array}{c}0.09 \\
(1.37)\end{array}$ & $\begin{array}{l}0.11 * * \\
(2.12)\end{array}$ & $\begin{array}{c}0.37 * * * \\
(4.14)\end{array}$ & $\begin{array}{c}0.29 * * \\
(2.30)\end{array}$ & $\begin{array}{c}0.34 * * \\
(2.20)\end{array}$ \\
\hline Q1 (Strong sell) & $\begin{array}{c}-1.80 * * * \\
(-12.09)\end{array}$ & $\begin{array}{c}0.45 * * * \\
(6.11)\end{array}$ & $\begin{array}{c}0.35 * * * \\
(6.39)\end{array}$ & $\begin{array}{c}0.83 * * * \\
(8.72)\end{array}$ & $\begin{array}{c}0.83 * * * \\
(6.20)\end{array}$ & $\begin{array}{c}1.06 * * * \\
(6.75)\end{array}$ \\
\hline Q5-Q1 & $\begin{array}{l}3.54 * * * \\
(12.09)\end{array}$ & $\begin{array}{c}-0.78 * * * \\
(-6.11)\end{array}$ & $\begin{array}{c}-0.61 * * * \\
(-6.39)\end{array}$ & $\begin{array}{c}-1.12 * * * \\
(-8.72)\end{array}$ & $\begin{array}{c}-1.69 * * * \\
(-6.20)\end{array}$ & $\begin{array}{c}-2.64 * * * \\
(-6.75)\end{array}$ \\
\hline \multicolumn{7}{|c|}{ Panel B. Regressions of Pre-Announcement, Announcement, and Post-Announcement CARs } \\
\hline $\operatorname{CAID}_{[-40,-1]}$ & $\begin{array}{c}0.0010 * * * \\
(9.552)\end{array}$ & $\begin{array}{c}-0.0002 * * * \\
(-6.574)\end{array}$ & $\begin{array}{c}-0.0002 * * * \\
(-7.108)\end{array}$ & $\begin{array}{c}-0.0003 * * * \\
(-5.839)\end{array}$ & $\begin{array}{c}-0.0005 * * * \\
(-5.001)\end{array}$ & $\begin{array}{c}-0.0007 * * * \\
(-6.067)\end{array}$ \\
\hline $\operatorname{CAR}_{[-40,-1]}$ & & $\begin{array}{c}-0.0132 * * * \\
(-3.297)\end{array}$ & $\begin{array}{c}-0.0158 * * * \\
(-3.386)\end{array}$ & $\begin{array}{c}-0.0292 * * * \\
(-2.592)\end{array}$ & $\begin{array}{c}-0.0483 * * * \\
(-2.874)\end{array}$ & $\begin{array}{c}-0.0524 * * \\
(-2.489)\end{array}$ \\
\hline Control variables & Yes & Yes & Yes & Yes & Yes & Yes \\
\hline$R^{2}(\%)$ & 0.72 & 0.34 & 0.34 & 0.45 & 0.62 & 0.53 \\
\hline Adjusted $R^{2}(\%)$ & 0.70 & 0.32 & 0.32 & 0.43 & 0.60 & 0.51 \\
\hline
\end{tabular}




\section{TABLE 3}

\section{Analysis of CARs around Actual and Pseudo Earnings Announcements}

In Table 3, for each actual earnings announcement, the pseudo announcement date is determined by subtracting a random number of trading days from the actual announcement date, which is drawn from a uniform distribution spanning from 21 to 39 . For each actual or pseudo earnings announcement, $\mathrm{CAR}_{\left[t_{1}, t_{2}\right]}$ denotes the cumulative abnormal return from day $t_{1}$ to day $t_{2}$ and $\operatorname{CAID}_{\left[t_{1}, t_{2}\right]}$ the cumulative abnormal institutional demand. In Panel A, the actual and pseudo earnings announcements are sorted into quintiles based on $\operatorname{CAID}_{[-20,-1]}$. The panel first reports the differences of CAID $\left[t_{1}, t_{2}\right]$ and $\mathrm{CAR}_{\left[t_{1}, t_{2}\right]}$ between Q5 and Q1, where Q5 and Q1 are the quintiles of sample stocks strongly bought and sold by institutions in the pre-announcement period. It then reports difference in difference, i.e., the difference between the actual and pseudo announcements in the difference of CAID $\left[t_{1}, t_{2}\right]$ or CAR $\left[t_{1}, t_{2}\right]$ between Q5 and Q1. Returns are reported in percentage terms. Panel B examines the relationship between pre-announcement CAID and subsequent CAR by the following regression on the sample of pseudo earnings announcements:

$$
\operatorname{CAR}_{\left[t_{1}, t_{2}\right]}=\beta_{0}+\beta_{1} \operatorname{CAID}_{\left[t_{1}^{*}, t_{2}^{*}\right]}+\beta_{2} \operatorname{CAR}_{\left[t_{1}^{*}, t_{2}^{*}\right]}+\sum_{i=1}^{12} \gamma_{i} \mathrm{CV}_{i}+\varepsilon \text {, }
$$

where $\left[t_{1}^{*}, t_{2}^{*}\right]$ indicates the period from day $t_{1}^{*}$ to $t_{2}^{*}$ and $\mathrm{CV}_{i}$ are control variables estimated in the year prior to the earnings announcements, including stock size, which is the logarithm of the average daily market capitalization, stock price, stock illiquidity, market beta, idiosyncratic volatility, bid-ask spread, institutional ownership, analyst coverage, book-to-market ratio, probability of information-based trading, firm age, and dispersion in analyst forecasts of the stock. T-statistics are shown in parentheses. Symbols ***, ** and * indicate significance at the 1\%, 5\%, and 10\% levels, respectively. Standard errors are clustered by stock and calendar quarter (Petersen (2009)) and the 2-way cluster-robust t-statistics are reported for regression analysis.

Panel A. Differences in CAID and CARs around Actual and Pseudo Earnings Announcements Conditional on $\underline{C A I D}[-20,-1]$

\begin{tabular}{|c|c|c|c|c|c|c|}
\hline & $\mathrm{CAID}_{[-20,-1]}$ & $\operatorname{CAR}_{[-20,-1]}$ & $\operatorname{CAR}_{[0,1]}$ & $\operatorname{CAR}_{[2,6]}$ & $\mathrm{CAR}_{[2,10]}$ & $\operatorname{CAR}_{[2,20]}$ \\
\hline \multicolumn{7}{|c|}{ Actual Earnings Announcements } \\
\hline $\mathrm{Q} 5-\mathrm{Q} 1$ & $\begin{array}{c}21.14 * * * \\
(98.66)\end{array}$ & $\begin{array}{c}3.21 * * * \\
(11.27)\end{array}$ & $\begin{array}{c}-0.57 * * * \\
(-4.93)\end{array}$ & $\begin{array}{c}-0.46^{* * *} \\
(-4.87)\end{array}$ & $\begin{array}{c}-0.74 * * * \\
(-5.13)\end{array}$ & $\begin{array}{c}-1.10 * * * \\
(-5.00)\end{array}$ \\
\hline \multicolumn{7}{|c|}{ Pseudo Earnings Announcements } \\
\hline $\mathrm{Q} 5-\mathrm{Q} 1$ & $\begin{array}{c}21.21 * * * \\
(95.68)\end{array}$ & $\begin{array}{c}3.15 * * * \\
(11.61)\end{array}$ & $\begin{array}{c}-0.08 \\
(-1.32)\end{array}$ & $\begin{array}{c}-0.15 \\
(-1.62)\end{array}$ & $\begin{array}{l}-0.31 * \\
(-1.91)\end{array}$ & $\begin{array}{c}-0.57 * * \\
(-2.06)\end{array}$ \\
\hline \multicolumn{7}{|c|}{ Differences Between Actual and Pseudo Earnings Announcements } \\
\hline Diff. in (Q5-Q1) & $\begin{array}{c}-0.07 \\
(-0.22)\end{array}$ & $\begin{array}{c}0.07 \\
(0.16)\end{array}$ & $\begin{array}{c}-0.49 * * * \\
(-3.82)\end{array}$ & $\begin{array}{c}-0.31 * * \\
(-2.09)\end{array}$ & $\begin{array}{c}-0.42 * * \\
(-2.01)\end{array}$ & $\begin{array}{c}-0.53 * \\
(-1.68)\end{array}$ \\
\hline
\end{tabular}

Panel B. Regressions of CARs on the Sample of Pseudo Earnings Announcements

\begin{tabular}{|c|c|c|c|c|c|}
\hline & $\operatorname{CAR}_{[-20,-1]}$ & $\mathrm{CAR}_{[0,1]}$ & $\mathrm{CAR}_{[2,6]}$ & $\operatorname{CAR}_{[2,10]}$ & $\operatorname{CAR}_{[2,20]}$ \\
\hline $\operatorname{CAID}_{[-20,-1]}$ & $\begin{array}{c}0.0025 * * * \\
(9.960)\end{array}$ & $\begin{array}{c}-0.00002 \\
(-0.854)\end{array}$ & $\begin{array}{c}-0.00003 \\
(-1.024)\end{array}$ & $\begin{array}{c}-0.00007 \\
(-1.420)\end{array}$ & $\begin{array}{l}-0.0002 \\
(-1.621)\end{array}$ \\
\hline $\operatorname{CAR}_{[-20,-1]}$ & & $\begin{array}{c}-0.0081 * * \\
(-2.069)\end{array}$ & $\begin{array}{c}-0.0179 * * \\
(-2.501)\end{array}$ & $\begin{array}{l}-0.0170 \\
(-1.558)\end{array}$ & $\begin{array}{l}-0.0290 \\
(-1.580)\end{array}$ \\
\hline Control variables & Yes & Yes & Yes & Yes & Yes \\
\hline$R^{2}(\%)$ & 1.22 & 0.11 & 0.15 & 0.14 & 0.25 \\
\hline Adjusted $R^{2}(\%)$ & 1.20 & 0.08 & 0.13 & 0.12 & 0.23 \\
\hline
\end{tabular}




\section{TABLE 4}

Overconfidence and Stock Characteristics

Table 4 evaluates the effects of stock characteristics (SCs) on overconfidence using the following regression model:

$$
\mathrm{CAR}_{[0,60]}=\beta_{0}+\beta_{1} \mathrm{CAID}_{[-40,-1]}+\beta_{2} \mathrm{CAID}_{[-40,-1]} \times \mathrm{SC}+\beta_{3} \mathrm{CAR}_{[-40,-1]}+\beta_{4} \mathrm{SC}+\sum_{i=1}^{12} \gamma_{i} \mathrm{CV}_{i}+\varepsilon,
$$

where $\operatorname{CAR}_{[0,60]}$ is the cumulative abnormal return from day 0 to day 60 and $\operatorname{CAID}_{[-40,-1]}$ is the cumulative abnormal institutional demand over day -40 through day -1 . Stock characteristic SCs are selected for their close relationships with information asymmetry and/or stock valuation difficulty, including probability of information-based trading (PIN), idiosyncratic volatility (IDIOV), bid-ask spread (SPREAD), stock size (SIZE), firm age (AGE), analyst coverage (ACOVERAGE), dispersion in analyst forecasts (DISP), share turnover (TO), research and development intensity (R\&D), earnings quality (EARNINGSQ), cash flow volatility (CASHFLOWV), and earnings volatility (EARNINGSV). $\mathrm{CV}_{i}$ in the model are control variables estimated in the year prior to the earnings announcements, including stock size, which is the logarithm of the average daily market capitalization, stock price, stock illiquidity, market beta, idiosyncratic volatility, bid-ask spread, institutional ownership, analyst coverage, book-to-market ratio, probability of informationbased trading, firm age, and dispersion in analyst forecasts of the stock. Standard errors are clustered by stock and calendar quarter (Petersen (2009)) and the 2-way cluster-robust t-statistics are reported in parentheses. Symbols ***, $* *$ and $*$ indicate significance at the $1 \%, 5 \%$, and $10 \%$ levels, respectively.

\begin{tabular}{|c|c|c|c|c|c|c|}
\hline & \multicolumn{6}{|c|}{$\mathrm{SC}=$} \\
\hline & PIN & IDIOV & SPREAD & SIZE & AGE & ACOVERAGE \\
\hline $\operatorname{CAID}_{[-40,-1]}$ & $\begin{array}{c}-0.0007 * * * \\
(-3.705)\end{array}$ & $\begin{array}{c}0.0007 * * \\
(2.445)\end{array}$ & $\begin{array}{c}-0.0007 * * * \\
(-5.718)\end{array}$ & $\begin{array}{c}-0.0007 * * * \\
(-5.695)\end{array}$ & $\begin{array}{c}-0.0014 * * * \\
(-7.406)\end{array}$ & $\begin{array}{c}-0.0014 * * * \\
(-7.381)\end{array}$ \\
\hline $\operatorname{CAID}_{[-40,-1]} \times \mathrm{SC}$ & $\begin{array}{c}-0.0028^{* *} \\
(-2.058)\end{array}$ & $\begin{array}{c}-0.0588^{* * * *} \\
(-4.619)\end{array}$ & $\begin{array}{c}-0.0300^{* * * *} \\
(-2.359)\end{array}$ & $\begin{array}{c}0.0003 * * * \\
(5.165)\end{array}$ & $\begin{array}{l}0.00003 * * * \\
\quad(4.991)\end{array}$ & $\begin{array}{c}0.00006^{* *} \\
(4.201)\end{array}$ \\
\hline $\operatorname{CAR}_{[-40,-1]}$ & $\begin{array}{c}-0.0655^{* * *} \\
(-2.876)\end{array}$ & $\begin{array}{c}-0.0636 * * * \\
(-2.837)\end{array}$ & $\begin{array}{c}-0.0653 * * * \\
(-2.876)\end{array}$ & $\begin{array}{c}-0.0651^{* * * *} \\
(-2.861)\end{array}$ & $\begin{array}{c}-0.0648 * * * \\
(-2.855)\end{array}$ & $\begin{array}{c}-0.0654 * * * \\
(-2.874)\end{array}$ \\
\hline SC & $\begin{array}{l}0.0667^{*} \\
(1.776)\end{array}$ & $\begin{array}{l}-0.2913 \\
(-0.582)\end{array}$ & $\begin{array}{l}1.1257 \\
(1.550)\end{array}$ & $\begin{array}{l}0.0026 \\
(1.241)\end{array}$ & $\begin{array}{c}0.00005 \\
(0.841)\end{array}$ & $\begin{array}{l}0.0004 \\
(0.845)\end{array}$ \\
\hline $\begin{array}{l}\text { Control variables } \\
R^{2}(\%) \\
\text { Adjusted } R^{2}(\%)\end{array}$ & $\begin{array}{l}\text { Yes } \\
0.72 \\
0.70\end{array}$ & $\begin{array}{l}\text { Yes } \\
0.92 \\
0.90\end{array}$ & $\begin{array}{l}\text { Yes } \\
0.72 \\
0.70\end{array}$ & $\begin{array}{l}\text { Yes } \\
0.77 \\
0.75\end{array}$ & $\begin{array}{l}\text { Yes } \\
0.77 \\
0.75\end{array}$ & $\begin{array}{l}\text { Yes } \\
0.75 \\
0.73\end{array}$ \\
\hline \multirow{2}{*}{ Adjusted $R^{2}(\%)$} & \multicolumn{6}{|c|}{$\mathrm{SC}=$} \\
\hline & DISP & TO & $R \& D$ & EARNINGSQ & CASHFLOWV & EARNINGSV \\
\hline $\operatorname{CAID}_{[-40,-1]}$ & $\begin{array}{c}-0.0007 * * * \\
(-6.314)\end{array}$ & $\begin{array}{c}-0.0005 * * * \\
(-2.947)\end{array}$ & $\begin{array}{c}-0.0007 * * * \\
(-6.109)\end{array}$ & $\begin{array}{c}-0.0006^{* * * *} \\
(-4.382)\end{array}$ & $\begin{array}{c}-0.0007 * * * \\
(-6.267)\end{array}$ & $\begin{array}{c}-0.0008^{* * *} \\
(-7.571)\end{array}$ \\
\hline $\operatorname{CAID}_{[-40,-1]} \times \mathrm{SC}$ & $\begin{array}{c}-0.0015^{* *} \\
(-3.542)\end{array}$ & $\begin{array}{c}-0.0448^{* *} \\
(-2.360)\end{array}$ & $\begin{array}{c}-0.0052^{* * * *} \\
(-3.368)\end{array}$ & $\begin{array}{c}0.0072 * * * \\
(3.315)\end{array}$ & $\begin{array}{c}-0.0088^{* * *} \\
(-2.625)\end{array}$ & $\begin{array}{c}-0.0014^{* *} \\
(-2.288)\end{array}$ \\
\hline $\operatorname{CAR}_{[-40,-1]}$ & $\begin{array}{c}-0.0655^{* * *} \\
(-2.885)\end{array}$ & $\begin{array}{c}-0.0655^{* * * *} \\
(-2.877)\end{array}$ & $\begin{array}{c}-0.0647 * * * \\
(-2.851)\end{array}$ & $\begin{array}{c}-0.0660^{* * *} \\
(-2.988)\end{array}$ & $\begin{array}{c}-0.0661 * * * \\
(-2.927)\end{array}$ & $\begin{array}{c}-0.0668 * * * \\
(-2.954)\end{array}$ \\
\hline SC & $\begin{array}{l}-0.0010 \\
(-0.156)\end{array}$ & $\begin{array}{c}-0.8791 * * * \\
(-2.718)\end{array}$ & $\begin{array}{l}0.0364 \\
(1.108)\end{array}$ & $\begin{array}{l}-0.0321 \\
(-1.303)\end{array}$ & $\begin{array}{c}-0.1137 * * \\
(-2.258)\end{array}$ & $\begin{array}{l}-0.0095 \\
(-1.483)\end{array}$ \\
\hline Control variables & Yes & Yes & Yes & Yes & Yes & Yes \\
\hline$R^{2}(\%)$ & 0.73 & 0.79 & 0.79 & 0.81 & 0.78 & 0.73 \\
\hline Adjusted $R^{2}(\%)$ & 0.71 & 0.77 & 0.77 & 0.79 & 0.76 & 0.70 \\
\hline
\end{tabular}


TABLE 5

Nonparametric Analysis of the Self-Attribution Hypothesis

Table 5 presents the sorting analysis of post-announcement CARs conditional on pre-announcement CAID and earnings surprise (SUE) to examine the selfattribution hypothesis. $\mathrm{CAR}_{\left[t_{1}, t_{2}\right]}$ is the cumulative abnormal return from day $t_{1}$ to day $t_{2}, \operatorname{CAID}_{[-40,-1]}$ the cumulative abnormal institutional demand from day -40 to day -1 , and $\mathrm{SUE}_{\text {next }}$ earnings surprise of the next earnings announcement. Stocks are first sorted into quintiles based on CAID $[-40,-1]$, where $Q\left(\operatorname{CAID}_{[-40,-1]}\right)=5$ and $Q\left(\operatorname{CAID}_{[-40,-1]}\right)=1$ denote the quintiles of stocks strongly bought and sold by institutions in the pre-announcement period, respectively. Within each of the quintiles, stocks are further sorted into quintiles based on standardized unexpected earnings (SUE), where $Q$ (SUE) $=5$ and $Q$ (SUE) $=1$ denote the quintiles with the highest and lowest SUE, respectively. The table documents the average post-announcement CARs of stocks in four subsamples. Returns are reported in percentage terms. Symbols $* * *, * *$ and $*$ indicate significance at the $1 \%, 5 \%$, and $10 \%$ levels, respectively. CAR diff. columns report the average CAR difference between the earlier and later periods, where $p$-value in square brackets stands for the hypothesis test on whether the difference is greater than 0 (labeled by superscript + ) or smaller than 0 (labeled by superscript - ). 
Table 5 (continued)

\begin{tabular}{|c|c|c|c|c|c|c|c|}
\hline & $\operatorname{CAR}_{[2,60]}$ & $\mathrm{CAR}_{[61,120]}$ & CAR diff. & SUE $_{\text {next }}$ & $\operatorname{CAR}_{[2,10]}$ & $\operatorname{CAR}_{[11,20]}$ & CAR diff. \\
\hline $\begin{array}{l}Q\left(\operatorname{CAID}_{[-40,-1]}\right)=5 \text { and } Q(\mathrm{SUE})=5, \text { (strong buys } \\
\text { followed by confirming news) }\end{array}$ & $\begin{array}{c}-0.57 \\
(-1.573)\end{array}$ & $\begin{array}{l}-1.38 * * * \\
(-3.548)\end{array}$ & $\begin{array}{c}0.82 \\
{[0.0547]^{+}}\end{array}$ & $\begin{array}{l}2.37 * * * \\
(21.574)\end{array}$ & $\begin{array}{c}0.52 * * * \\
(3.659)\end{array}$ & $\begin{array}{c}0.04 \\
(0.291)\end{array}$ & $\begin{array}{c}0.48 \\
{[0.0076]^{+}}\end{array}$ \\
\hline $\begin{array}{l}Q\left(\operatorname{CAID}_{[-40,-1]}\right)=5 \text { and } Q(\mathrm{SUE})=1, \text { (strong buys } \\
\text { followed by disconfirming news) }\end{array}$ & $\begin{array}{c}-2.58 * * * \\
(-6.501)\end{array}$ & $\begin{array}{c}-0.46 \\
(-1.068)\end{array}$ & $\begin{array}{c}-2.12 \\
{[0.0001]^{-}}\end{array}$ & $\begin{array}{c}-1.22 * * * \\
(-5.209)\end{array}$ & $\begin{array}{c}-1.00 * * * \\
(-6.160)\end{array}$ & $\begin{array}{l}-0.09 \\
(-0.521)\end{array}$ & $\begin{array}{c}-0.91 \\
{[0.0001]^{-}}\end{array}$ \\
\hline $\begin{array}{l}Q\left(\operatorname{CAID}_{[-40,-1]}\right)=1 \text { and } Q(\mathrm{SUE})=5, \text { (strong sells } \\
\text { followed by disconfirming news) }\end{array}$ & $\begin{array}{l}1.19 * * * \\
(3.557)\end{array}$ & $\begin{array}{c}0.52 \\
(1.321)\end{array}$ & $\begin{array}{c}0.67 \\
{[0.0988]^{+}}\end{array}$ & $\begin{array}{l}2.33 * * * \\
(9.955)\end{array}$ & $\begin{array}{l}0.81 * * * \\
(5.773)\end{array}$ & $\begin{array}{c}0.21 \\
(1.474)\end{array}$ & $\begin{array}{c}0.60 \\
{[0.0001]^{+}}\end{array}$ \\
\hline $\begin{array}{l}Q\left(\operatorname{CAID}_{[-40,-1]}\right)=1 \text { and } Q(\mathrm{SUE})=1,(\text { strong sells } \\
\text { followed by confirming news })\end{array}$ & $\begin{array}{c}0.60 \\
(1.511)\end{array}$ & $\begin{array}{l}1.25 * * * \\
(2.701)\end{array}$ & $\begin{array}{c}-0.65 \\
{[0.1431]^{-}}\end{array}$ & $\begin{array}{c}-1.07 * * * \\
(-5.138)\end{array}$ & $\begin{array}{c}0.20 \\
(1.099)\end{array}$ & $\begin{array}{c}0.13 \\
(0.821)\end{array}$ & $\begin{array}{c}0.07 \\
{[0.3948]^{+}}\end{array}$ \\
\hline
\end{tabular}

\begin{tabular}{|c|c|c|c|c|c|c|}
\hline & $\operatorname{CAR}_{[2,20]}$ & $\operatorname{CAR}_{[21,40]}$ & CAR diff. & $\operatorname{CAR}_{[2,30]}$ & $\operatorname{CAR}_{[31,60]}$ & CAR diff. \\
\hline $\begin{array}{l}Q\left(\text { CAID }_{[-40,-1]}\right)=5 \text { and } Q(\mathrm{SUE})=5, \text { (strong buys followed by } \\
\text { confirming news })\end{array}$ & $\begin{array}{l}0.56^{* * * *} \\
(2.819)\end{array}$ & $\begin{array}{c}-0.74 * * * \\
(-3.522)\end{array}$ & $\begin{array}{c}1.31 \\
{[0.0000]^{+}}\end{array}$ & $\begin{array}{l}0.23 \\
(0.950)\end{array}$ & $\begin{array}{l}-0.80 * * * \\
(-3.081)\end{array}$ & $\begin{array}{c}1.03 \\
{[0.0016]^{+}}\end{array}$ \\
\hline $\begin{array}{l}Q\left(\mathrm{CAID}_{[-40,-1]}\right)=5 \text { and } Q(\mathrm{SUE})=1, \text { (strong buys followed by } \\
\text { disconfirming news) }\end{array}$ & $\begin{array}{c}-1.09 * * * \\
(-4.698)\end{array}$ & $\begin{array}{l}-0.54 * * \\
(-2.315)\end{array}$ & $\begin{array}{c}-0.54 \\
{[0.0559]^{-}}\end{array}$ & $\begin{array}{c}-1.24 * * * \\
(-4.555)\end{array}$ & $\begin{array}{c}-1.34 * * * \\
(-4.475)\end{array}$ & $\begin{array}{l}0.10 \\
{[0.4068]^{+}}\end{array}$ \\
\hline $\begin{array}{l}Q\left(\mathrm{CAID}_{[-40,-1]}\right)=1 \text { and } Q(\mathrm{SUE})=5, \text { (strong sells followed by } \\
\text { disconfirming news) }\end{array}$ & $\begin{array}{l}1.02 * * * \\
(5.126)\end{array}$ & $\begin{array}{l}0.07 \\
(0.336)\end{array}$ & $\begin{array}{c}0.95 \\
{[0.0005]^{+}}\end{array}$ & $\begin{array}{l}1.20 * * * \\
(4.906)\end{array}$ & $\begin{array}{c}-0.01 \\
(-0.031)\end{array}$ & $\begin{array}{c}1.21 \\
{[0.0005]^{+}}\end{array}$ \\
\hline $\begin{array}{l}Q\left(\mathrm{CAID}_{[-40,-1]}\right)=1 \text { and } Q(\mathrm{SUE})=1,(\text { strong sells followed by } \\
\text { confirming news })\end{array}$ & $\begin{array}{c}0.34 \\
(1.414) \\
\end{array}$ & $\begin{array}{c}0.22 \\
(0.847)\end{array}$ & $\begin{array}{c}0.12 \\
{[0.3704]^{+}}\end{array}$ & $\begin{array}{l}0.67 * * \\
(2.271)\end{array}$ & $\begin{array}{l}-0.08 \\
(-0.264)\end{array}$ & $\begin{array}{c}0.75 \\
{[0.0442]^{+}}\end{array}$ \\
\hline
\end{tabular}


TABLE 6

Nonparametric Analysis of the Self-Attribution Hypothesis: Actual versus Pseudo Earnings Announcements

Table 6 presents the sorting analysis of post-announcement CARs conditional on pre-announcement CAID and announcement CAR for actual and pseudo earnings announcements. For each actual earnings announcement, the pseudo announcement date is determined by subtracting a random number of trading days from the actual announcement date, which is drawn from a uniform distribution spanning from 21 to 39 . For each actual or pseudo earnings announcement, CAR $\left[t_{1}, t_{2}\right]$ denotes the cumulative abnormal return from day $t_{1}$ to day $t_{2}$ and $\mathrm{CAID}_{\left[t_{1}, t_{2}\right]}$ the cumulative abnormal institutional demand. Actual and pseudo earnings announcements are sorted into quintiles based on $\operatorname{CAID}_{[-20,-1]}$, where $Q\left(\operatorname{CAID}_{[-20,-1]}\right)=5$ and $Q\left(\operatorname{CAID}_{[-20,-1]}\right)=1$ denote the quintiles of stocks strongly bought and sold by institutions in the pre-announcement period, respectively. Within each of the quintiles, stocks are further sorted into quintiles based on $\mathrm{CAR}_{[0,1]}$, where $Q\left(\mathrm{CAR}_{[0,1]}\right)=5$ and $Q\left(\mathrm{CAR}_{[0,1]}\right)=1$ denote the quintiles with the highest and lowest announcement CAR, respectively. The table documents the average post-announcement CARs of stocks in the four subsamples. Returns are reported in percentage terms. T-statistics are shown in parentheses. Symbols $* * *, * *$ and * indicate significance at the $1 \%, 5 \%$, and $10 \%$ levels, respectively. The third and sixth columns (CAR diff.) report the average CAR difference between the earlier and later periods, where $p$-value in square brackets stands for the hypothesis test on whether the difference is greater than 0 (labeled by superscript + ) or smaller than 0 (labeled by superscript -). The last two columns document the average CAR difference between the actual and pseudo earnings announcements, where $p$ value in square brackets stands for the hypothesis test on whether the difference is equal to 0 .

\begin{tabular}{|c|c|c|c|c|c|c|c|c|}
\hline & \multicolumn{3}{|c|}{ Actual Announcements } & \multicolumn{3}{|c|}{ Pseudo Announcements } & \multicolumn{2}{|c|}{$\mathrm{CAR}_{\text {actual }}-\mathrm{CAR}_{\text {pseudo }}$} \\
\hline & $\operatorname{CAR}_{[2,10]}$ & $\operatorname{CAR}_{[11,20]}$ & $\begin{array}{c}\text { CAR } \\
\text { diff. }\end{array}$ & $\operatorname{CAR}_{[2,10]}$ & $\operatorname{CAR}_{[11,20]}$ & $\begin{array}{c}\text { CAR } \\
\text { diff. }\end{array}$ & $\mathrm{CAR}_{[2,10]}$ & $\operatorname{CAR}_{[11,20]}$ \\
\hline $\begin{array}{l}Q\left(\operatorname{CAID}_{[-20,-1]}\right)=5 \text { and } Q(\mathrm{SUE})=5,(\text { strong buys } \\
\text { followed by confirming news })\end{array}$ & $\begin{array}{c}0.30^{*} \\
(1.926)\end{array}$ & $\begin{array}{l}-0.33 * * \\
(-2.207)\end{array}$ & $\begin{array}{c}0.63 \\
{[0.0021]^{+}}\end{array}$ & $\begin{array}{c}-0.53 * * * \\
(-2.945)\end{array}$ & $\begin{array}{l}-0.48 * * \\
(-2.524)\end{array}$ & $\begin{array}{c}-0.04 \\
{[0.4314]^{-}}\end{array}$ & $\begin{array}{c}0.83 \\
{[0.0004]}\end{array}$ & $\begin{array}{c}0.16 \\
{[0.5223]}\end{array}$ \\
\hline $\begin{array}{l}Q\left(\operatorname{CAID}_{[-20,-1]}\right)=5 \text { and } Q(\mathrm{SUE})=1, \text { (strong buys } \\
\text { followed by disconfirming news) }\end{array}$ & $\begin{array}{l}-1.11 * * * \\
(-6.216)\end{array}$ & $\begin{array}{c}0.03 \\
(0.186)\end{array}$ & $\begin{array}{c}-1.14 \\
{[0.0000]^{-}}\end{array}$ & $\begin{array}{l}-0.16 \\
(-0.827)\end{array}$ & $\begin{array}{c}-0.48 * * \\
(2.497)\end{array}$ & $\begin{array}{c}0.32 \\
{[0.1171]^{+}}\end{array}$ & $\begin{array}{c}-0.95 \\
{[0.0003]}\end{array}$ & $\begin{array}{c}0.52 \\
{[0.0539]}\end{array}$ \\
\hline $\begin{array}{l}Q\left(\operatorname{CAID}_{[-20,-1]}\right)=1 \text { and } Q(\mathrm{SUE})=5, \text { (strong sells } \\
\text { followed by disconfirming news) }\end{array}$ & $\begin{array}{l}0.80 * * * \\
(4.677)\end{array}$ & $\begin{array}{l}0.64 * * * \\
(3.717)\end{array}$ & $\begin{array}{c}0.16 \\
{[0.2548]^{+}}\end{array}$ & $\begin{array}{c}-0.03 \\
(-0.162)\end{array}$ & $\begin{array}{c}0.04 \\
(0.183)\end{array}$ & $\begin{array}{c}-0.07 \\
{[0.4058]^{-}}\end{array}$ & $\begin{array}{c}0.83 \\
{[0.0009]}\end{array}$ & $\begin{array}{c}0.61 \\
{[0.0212]}\end{array}$ \\
\hline $\begin{array}{l}Q\left(\operatorname{CAID}_{[-20,-1]}\right)=1 \text { and } Q(\mathrm{SUE})=1,(\text { strong sells } \\
\text { followed by confirming news })\end{array}$ & $\begin{array}{c}0.25 \\
(1.287)\end{array}$ & $\begin{array}{l}0.44 * * \\
(2.278)\end{array}$ & $\begin{array}{c}-0.18 \\
{[0.2652]^{-}}\end{array}$ & $\begin{array}{l}0.50 * * \\
(2.500)\end{array}$ & $\begin{array}{c}0.11 \\
(0.550)\end{array}$ & $\begin{array}{c}0.39 \\
{[0.0927]^{+}}\end{array}$ & $\begin{array}{c}-0.25 \\
{[0.3798]}\end{array}$ & $\begin{array}{c}0.32 \\
{[0.2517]}\end{array}$ \\
\hline
\end{tabular}


TABLE 7

Regression Tests for the Self-Attribution Hypothesis

Panel A and Panel B of Table 7 test the self-attribution hypothesis using the following regression models, respectively:

$$
\begin{aligned}
& \operatorname{CAR}_{\left[t_{1}, t_{2}\right]}=\beta_{0}+\beta_{1} \operatorname{CAID}_{[-40,-1]} \times \mathbf{I}\left(\operatorname{SUE} \times \operatorname{CAID}_{[-40,-1]}>0\right)+\beta_{2} \operatorname{CAID}_{[-40,-1]} \times \mathbf{I}\left(\operatorname{SUE} \times \operatorname{CAID}_{[-40,-1]} \leq 0\right)+\beta_{3} \operatorname{CAR}_{[-40,-1]}+\sum_{i=1}^{12} \gamma_{i} \operatorname{CV}_{i}+\varepsilon \\
& \operatorname{CAR}_{\left[t_{1}, t_{2}\right]}=\beta_{0}+\beta_{1} \operatorname{CAID}_{[-40,-1]} \times \mathbf{I}\left(\operatorname{SUE} \times \operatorname{CAID}_{[-40,-1]}>0\right) \times|\operatorname{SUE}|+\beta_{2} \operatorname{CAID}_{[-40,-1]} \times \mathbf{I}\left(\operatorname{SUE} \times \operatorname{CAID}_{[-40,-1]} \leq 0\right) \times|\operatorname{SUE}| \\
& +\beta_{3} \mathrm{CAR}_{[-40,-1]}+\beta_{4}|\mathrm{SUE}|+\sum_{i=1}^{12} \gamma_{i} \mathrm{CV}_{i}+\varepsilon \text {, }
\end{aligned}
$$

where $\mathrm{CAR}_{\left[t_{1}, t_{2}\right]}$ is the cumulative abnormal return from day $t_{1}$ to day $t_{2}, \operatorname{CAID}_{[-40,-1]}$ the cumulative abnormal institutional demand over day -40 to day -1 , SUE the standardized unexpected earnings. $I(x>0)$ is equal to 1 if $x>0$ is true and 0 otherwise. Control variables $\mathrm{CV}_{i}$ are estimated in the year prior to the earnings announcements including stock size, stock price, stock illiquidity, market beta, idiosyncratic volatility, bid-ask spread, institutional ownership, analyst coverage, book-to-market ratio, probability of information-based trading, firm age, and dispersion in analyst forecasts. Standard errors are clustered by stock and calendar quarter (Petersen (2009)) and the 2-way cluster-robust t-statistics are reported in parentheses. Symbols ***, ** and * indicate significance at the 1\%, 5\%, and 10\% levels, respectively. 
Table 7 (continued)

Panel A. Tests for the Self-Attribution Hypothesis Considering SUE Direction Only

\begin{tabular}{|c|c|c|c|c|c|c|c|c|}
\hline & $\operatorname{CAR}_{[2,60]}$ & $\mathrm{CAR}_{[61,120]}$ & $\mathrm{CAR}_{[2,10]}$ & $\mathrm{CAR}_{[11,20]}$ & $\mathrm{CAR}_{[2,20]}$ & $\mathrm{CAR}_{[21,40]}$ & $\mathrm{CAR}_{[2,30]}$ & $\mathrm{CAR}_{[31,60]}$ \\
\hline $\mathrm{CAID}_{[-40,-1]} \times \boldsymbol{I}\left(\mathrm{SUE} \times \mathrm{CAID}_{[-40,-1]}>0\right)$ & $\begin{array}{c}-0.0004 * * \\
(-2.413)\end{array}$ & $\begin{array}{c}-0.0006^{* *} \\
(-2.887)\end{array}$ & $\begin{array}{l}0.00003 \\
(0.571)\end{array}$ & $\begin{array}{c}-0.0001 * * \\
(-2.330)\end{array}$ & $\begin{array}{l}-0.0001 \\
(-1.047)\end{array}$ & $\begin{array}{c}-0.0002 * * \\
(-2.067)\end{array}$ & $\begin{array}{c}-0.0002 * \\
(-1.849)\end{array}$ & $\begin{array}{c}-0.0002 * \\
(-1.753)\end{array}$ \\
\hline $\operatorname{CAID}_{[-40,-1]} \times I\left(\operatorname{SUE} \times \operatorname{CAID}_{[-40,-1]} \leq 0\right)$ & $\begin{array}{c}-0.0009 * * * \\
(-5.038)\end{array}$ & $\begin{array}{l}-0.0001 \\
(-1.024)\end{array}$ & $\begin{array}{c}-0.0005 * * * \\
(-10.019)\end{array}$ & $\begin{array}{c}-0.0001 * * \\
(-2.234)\end{array}$ & $\begin{array}{c}-0.0006 * * * \\
(-7.454)\end{array}$ & $\begin{array}{l}-0.0001 \\
(-0.645)\end{array}$ & $\begin{array}{c}-0.0006^{* * *} \\
(-5.456)\end{array}$ & $\begin{array}{c}-0.0004 * * * \\
(-3.112)\end{array}$ \\
\hline $\operatorname{CAR}_{[-40,-1]}$ & $\begin{array}{c}-0.053 * * \\
(-2.525)\end{array}$ & $\begin{array}{l}0.0001 \\
(0.004)\end{array}$ & $\begin{array}{c}-0.023^{* * *} \\
(-3.149)\end{array}$ & $\begin{array}{l}-0.0068 \\
(-0.970)\end{array}$ & $\begin{array}{c}-0.0302 * * * \\
(-2.665)\end{array}$ & $\begin{array}{l}-0.0189 \\
(-1.091)\end{array}$ & $\begin{array}{c}-0.0451 * * * \\
(-3.240)\end{array}$ & $\begin{array}{l}-0.0083 \\
(-0.514)\end{array}$ \\
\hline $\begin{array}{l}\text { Control variables } \\
R^{2}(\%) \\
\text { Adjusted } R^{2}(\%)\end{array}$ & $\begin{array}{l}\text { YES } \\
0.55 \\
0.53\end{array}$ & $\begin{array}{l}\text { YES } \\
0.89 \\
0.87\end{array}$ & $\begin{array}{l}\text { YES } \\
0.53 \\
0.51\end{array}$ & $\begin{array}{l}\text { YES } \\
0.18 \\
0.16\end{array}$ & $\begin{array}{l}\text { YES } \\
0.51 \\
0.49\end{array}$ & $\begin{array}{l}\text { YES } \\
0.25 \\
0.23\end{array}$ & $\begin{array}{l}\text { YES } \\
0.57 \\
0.55\end{array}$ & $\begin{array}{l}\text { YES } \\
0.18 \\
0.16\end{array}$ \\
\hline \multicolumn{9}{|c|}{ Panel B. Tests for the Self-Attribution Hypothesis Considering Both SUE Direction and Magnitude } \\
\hline & $\mathrm{CAR}_{[2,60]}$ & $\mathrm{CAR}_{[61,120]}$ & $\mathrm{CAR}_{[2,10]}$ & $\operatorname{CAR}_{[11,20]}$ & $\mathrm{CAR}_{[2,20]}$ & $\mathrm{CAR}_{[21,40]}$ & $\mathrm{CAR}_{[2,30]}$ & $\mathrm{CAR}_{[31,60]}$ \\
\hline $\operatorname{CAID}_{[-40,-1]} \times I\left(\operatorname{SUE} \times \operatorname{CAID}_{[-40,-1]}>0\right) \times|\mathrm{SUE}|$ & $\begin{array}{c}-0.00002 \\
(-0.376)\end{array}$ & $\begin{array}{c}-0.0001^{* *} \\
(-2.203)\end{array}$ & $\begin{array}{l}0.0001 * * \\
(2.538)\end{array}$ & $\begin{array}{l}-0.0000 \\
(-0.019)\end{array}$ & $\begin{array}{c}0.0001 * * * \\
(2.022)\end{array}$ & $\begin{array}{l}-0.0001 \\
(-1.555)\end{array}$ & $\begin{array}{c}0.00004 \\
(1.486)\end{array}$ & $\begin{array}{l}-0.0001 \\
(-1.487)\end{array}$ \\
\hline $\operatorname{CAID}_{[-40,-1]} \times I\left(\operatorname{SUE} \times \operatorname{CAID}_{[-40,-1]} \leq 0\right) \times|\operatorname{SUE}|$ & $\begin{array}{c}-0.0002 * * * \\
(-4.223)\end{array}$ & $\begin{array}{c}-0.00001 \\
(-0.186)\end{array}$ & $\begin{array}{c}-0.0001 * * * \\
(-5.575)\end{array}$ & $\begin{array}{c}-0.00004 * * \\
(-2.433)\end{array}$ & $\begin{array}{c}-0.0002 * * * \\
(-4.871)\end{array}$ & $\begin{array}{l}0.00000 \\
(0.079)\end{array}$ & $\begin{array}{c}-0.0002 * * * \\
(-5.486)\end{array}$ & $\begin{array}{l}-0.00003 \\
(-0.882)\end{array}$ \\
\hline $\operatorname{CAR}_{[-40,-1]}$ & $\begin{array}{c}-0.0564 * * * \\
(-2.667)\end{array}$ & $\begin{array}{l}-0.0009 \\
(-0.023)\end{array}$ & $\begin{array}{c}-0.0247 * * * \\
(-3.295)\end{array}$ & $\begin{array}{l}-0.0074 \\
(-1.058)\end{array}$ & $\begin{array}{c}-0.0321 * * * \\
(-2.807)\end{array}$ & $\begin{array}{c}-0.019 \\
(-1.118)\end{array}$ & $\begin{array}{c}-0.0473 * * * \\
(-3.359)\end{array}$ & $\begin{array}{c}-0.0473 * * * \\
(-3.359)\end{array}$ \\
\hline |SUE $\mid$ & $\begin{array}{c}0.0011 * * \\
(2.017)\end{array}$ & $\begin{array}{l}0.0001 \\
(0.247)\end{array}$ & $\begin{array}{c}-0.00003 * * \\
(-0.102)\end{array}$ & $\begin{array}{c}-0.00002 \\
(-0.148)\end{array}$ & $\begin{array}{c}-0.00005 \\
(-0.142)\end{array}$ & $\begin{array}{c}0.0009 * * \\
(2.066)\end{array}$ & $\begin{array}{l}0.0001 \\
(0.414)\end{array}$ & $\begin{array}{l}0.0001 \\
(0.414)\end{array}$ \\
\hline Control variables & YES & YES & YES & YES & YES & YES & YES & YES \\
\hline$R^{2}(\%)$ & 0.52 & 0.87 & 0.59 & 0.17 & 0.55 & 0.29 & 0.60 & 0.18 \\
\hline Adjusted $R^{2}(\%)$ & 0.50 & 0.85 & 0.56 & 0.15 & 0.53 & 0.27 & 0.58 & 0.16 \\
\hline
\end{tabular}


TABLE 8

Tests for the Self-Attribution Hypothesis Based on Post-Announcement Abnormal Institutional Demand

Panel A and Panel B of Table 8 test the self-attribution hypothesis using the following regression models, respectively:

$$
\begin{aligned}
& \operatorname{CAID}_{\left[t_{1}, t_{2}\right]}=\beta_{0}+\beta_{1} \operatorname{CAID}_{[-40,-1]} \times \mathbf{I}\left(\operatorname{SUE} \times \operatorname{CAID}_{[-40,-1]}>0\right)+\beta_{2} \operatorname{CAID}_{[-40,-1]} \times \mathbf{I}\left(\operatorname{SUE} \times \operatorname{CAID}_{[-40,-1]} \leq 0\right)+ \\
& \beta_{3} \mathrm{CAR}_{[-40,-1]}+\sum_{i=1}^{12} \gamma_{i} \mathrm{CV}_{i}+\varepsilon, \\
& \operatorname{CAID}_{\left[t_{1}, t_{2}\right]}=\beta_{0}+\beta_{1} \operatorname{CAID}_{[-40,-1]} \times \mathbf{I}\left(\mathrm{SUE} \times \mathrm{CAID}_{[-40,-1]}>0\right) \times|\mathrm{SUE}| \\
& +\beta_{2} \operatorname{CAID}_{[-40,-1]} \times \mathbf{I}\left(\mathrm{SUE} \times \mathrm{CAID}_{[-40,-1]} \leq 0\right) \times|\mathrm{SUE}| \\
& +\beta_{3} \mathrm{CAR}_{[-40,-1]}+\beta_{4}|\mathrm{SUE}|+\sum_{i=1}^{12} \gamma_{i} \mathrm{CV}_{i}+\varepsilon \text {, }
\end{aligned}
$$

where $\operatorname{CAID}_{\left[t_{1}, t_{2}\right]}$ is the cumulative abnormal institutional demand from day $t_{1}$ to day $t_{2}, \mathrm{CAR}_{\left[t_{1}, t_{2}\right]}$ the cumulative abnormal return, SUE the standardized unexpected earnings. $I(x>0)$ is equal to 1 if $x>0$ is true and 0 otherwise. Control variables $\mathrm{CV}_{i}$ are estimated in the year prior to the earnings announcements and include stock size, stock price, stock illiquidity, market beta, idiosyncratic volatility, bid-ask spread, institutional ownership, analyst coverage, bookto-market ratio, probability of information-based trading, firm age, and dispersion in analyst forecasts of the stock.

\begin{tabular}{|c|c|c|c|c|}
\hline $\operatorname{CAID}_{[-40,-1]} \times \boldsymbol{I}\left(\operatorname{SUE} \times \operatorname{CAID}_{[-40,-1]}>0\right)$ & $\begin{array}{c}0.0313 * * * \\
(5.659)\end{array}$ & $\begin{array}{c}-0.0482 * * * \\
(-7.271)\end{array}$ & $\begin{array}{c}-0.1699 * * * \\
(-10.118)\end{array}$ & $\begin{array}{c}-0.1867 * * * \\
(-9.057)\end{array}$ \\
\hline $\operatorname{CAID}_{[-40,-1]} \times \boldsymbol{I}\left(\operatorname{SUE} \times \operatorname{CAID}_{[-40,-1]} \leq 0\right)$ & $\begin{array}{c}-0.0196 * * * \\
(-3.235)\end{array}$ & $\begin{array}{c}-0.0788 * * * \\
(-10.260)\end{array}$ & $\begin{array}{c}-0.1617 * * * \\
(-8.913)\end{array}$ & $\begin{array}{c}-0.1486^{* * * *} \\
(-8.021)\end{array}$ \\
\hline $\operatorname{CAR}_{[-40,-1]}$ & $\begin{array}{c}1.3858 * * * \\
(5.461)\end{array}$ & $\begin{array}{c}1.0001 * * * \\
(4.193)\end{array}$ & $\begin{array}{c}0.8652 * * * \\
(2.985)\end{array}$ & $\begin{array}{c}1.0423 * * * \\
(2.620)\end{array}$ \\
\hline $\begin{array}{l}\text { Control variables } \\
R^{2}(\%) \\
\text { Adjusted } R^{2}(\%)\end{array}$ & $\begin{array}{l}\text { Yes } \\
0.35 \\
0.33\end{array}$ & $\begin{array}{l}\text { Yes } \\
1.09 \\
1.07\end{array}$ & $\begin{array}{l}\text { Yes } \\
2.86 \\
2.84\end{array}$ & $\begin{array}{l}\text { Yes } \\
2.74 \\
2.72\end{array}$ \\
\hline
\end{tabular}
Standard errors are clustered by stock and calendar quarter (Petersen (2009)) and the 2-way cluster-robust t-statistics are reported in parentheses. Symbols $* * *, * *$ and $*$ indicate significance at the $1 \%, 5 \%$, and $10 \%$ levels, respectively.

\begin{tabular}{|c|c|c|c|c|}
\hline $\operatorname{CAID}_{[-40,-1]} \times I\left(\operatorname{SUE} \times \operatorname{CAID}_{[-40,-1]}>0\right) \times|\operatorname{SUE}|$ & $\begin{array}{c}0.0067 * * * \\
(5.943)\end{array}$ & $\begin{array}{c}-0.0053 * * * \\
(-3.501)\end{array}$ & $\begin{array}{c}-0.0268 * * * \\
(-9.366)\end{array}$ & $\begin{array}{c}-0.0319 * * * \\
(-9.179)\end{array}$ \\
\hline $\operatorname{CAID}_{[-40,-1]} \times I\left(\operatorname{SUE} \times \operatorname{CAID}_{[-40,-1]} \leq 0\right) \times|\mathrm{SUE}|$ & $\begin{array}{c}-0.0065^{* * *} \\
(-5.072)\end{array}$ & $\begin{array}{c}-0.0162 * * * \\
(-9.798)\end{array}$ & $\begin{array}{c}-0.0251 * * * \\
(-6.420)\end{array}$ & $\begin{array}{c}-0.0214 * * * \\
(-6.136)\end{array}$ \\
\hline $\operatorname{CAR}_{[-40,-1]}$ & $\begin{array}{c}1.3799 * * * \\
(5.447)\end{array}$ & $\begin{array}{c}0.7769 * * * \\
(3.039)\end{array}$ & $\begin{array}{l}0.3751 \\
(1.390)\end{array}$ & $\begin{array}{l}0.5648 \\
(1.338)\end{array}$ \\
\hline$|\mathrm{SUE}|$ & $\begin{array}{c}0.0332 * * * \\
(3.159)\end{array}$ & $\begin{array}{l}0.0152 \\
(1.241)\end{array}$ & $\begin{array}{l}-0.0049 \\
(-0.284)\end{array}$ & $\begin{array}{l}0.0115 \\
(0.678)\end{array}$ \\
\hline Control variables & Yes & Yes & Yes & Yes \\
\hline$R^{2}(\%)$ & 0.39 & 0.64 & 1.14 & 1.12 \\
\hline Adjusted $R^{2}(\%)$ & 0.37 & 0.62 & 1.12 & 1.10 \\
\hline
\end{tabular}

$\operatorname{CAID}_{[2,20]} \quad \operatorname{CAID}_{[21,40]} \quad \operatorname{CAID}_{[41,80]} \quad \operatorname{CAID}_{[81,120]}$

Panel A. Tests for the Self-Attribution Hypothesis Considering SUE Direction Only

Panel B. Tests for the Self-Attribution Hypothesis Considering Both SUE Direction and Magnitude 


\section{TABLE 9}

\section{Trading Directions of Individual Institutions in Post-Announcement Periods}

Panel A of Table 9 divides observations into two subsamples: confirming news, i.e., SUE $\times \operatorname{CAIID}_{[-40,-1]}>0$, and disconfirming news, i.e., SUE $\times \operatorname{CAIID}_{[-40,-1]} \leq 0$, where $\operatorname{CAIID}_{[-40,-1]}$ is the cumulative abnormal demand of individual institutions over day -40 to day -1 and SUE is the standardized unexpected earnings. The panel reports the percentage of institutions continuing their pre-announcement trading directions in the post-announcement period of $\left[t_{1}, t_{2}\right]$. Panel $\mathrm{B}$ examines the probability of institutions continuing their pre-announcement trading directions in the post-announcement period of $\left[t_{1}, t_{2}\right]$ and reports the marginal effects of the following Probit regression models:

$$
\begin{gathered}
\operatorname{Pr}\left(\mathrm{CO}_{\left[t_{1}, t_{2}\right]}\right)=\Phi\left(\beta_{0}+\beta_{1} \mathbf{I}\left(\operatorname{SUE} \times \operatorname{CAIID}_{[-40,-1]}>0\right)+\beta_{2} \operatorname{CAIID}_{[-40,-1]}+\beta_{3} \mathrm{CAR}_{[-40,-1]}+\sum_{i=1}^{12} \gamma_{i} \mathrm{CV}_{i}+\varepsilon\right) \\
\operatorname{Pr}\left(\mathrm{CO}_{\left[t_{1}, t_{2}\right]}\right)=\Phi\left(\beta_{0}+\left(\beta_{1}+\beta_{2}|\mathrm{SUE}|\right) \boldsymbol{I}\left(\operatorname{SUE} \times \operatorname{CAIID}_{[-40,-1]}>0\right)+\beta_{3} \operatorname{CAIID}_{[-40,-1]}+\beta_{4} \mathrm{CAR}_{[-40,-1]}+\right. \\
\left.\beta_{5}|\mathrm{SUE}|+\sum_{i=1}^{12} \gamma_{i} \mathrm{CV}_{i}+\varepsilon\right),
\end{gathered}
$$

where the dummy variable $\mathrm{CO}_{\left[t_{1}, t_{2}\right]}$ takes the value of 1 if $\operatorname{CAIID}_{\left[t_{1}, t_{2}\right]} \times \operatorname{CAIID}_{[-40,-1]}>0$ and 0 otherwise, $\Phi(\cdot)$ is the cumulative distribution function of the standard normal distribution and $\operatorname{CAR}_{[-40,-1]}$ is the cumulative abnormal return from day -40 to day -1 ,. In the regressions, $I(x>0)$ is the indicator function taking the value of 1 if the condition $x>0$ is satisfied and 0 otherwise, while $\mathrm{CV}_{i}$ are control variables estimated in the year prior to the earnings announcements, including stock size, stock price, stock illiquidity, market beta, idiosyncratic volatility, bid-ask spread, institutional ownership, analyst coverage, book-to-market ratio, probability of information-based trading, firm age, and dispersion in analyst forecasts of the stock. Robust standard errors are clustered at the individual institution level and reported in parentheses. Symbols ***,** and * indicate significance at the $1 \%, 5 \%$, and $10 \%$ levels, respectively. 
Table 9 (continued)

Panel A. Individual Institutions' Trading Directions in the Post-Announcement Period

\begin{tabular}{lcccccc} 
& CAIID $_{[2,20]}$ & CAIID $_{[21,40]}$ & CAIID $_{[41,60]}$ & CAIID $_{[61,80]}$ & CAIID $_{[81,100]}$ & CAIID $_{[101,120]}$ \\
\hline Confirming news & $61.02 \%$ & $57.95 \%$ & $53.96 \%$ & $50.58 \%$ & $49.86 \%$ & $46.85 \%$ \\
Disconfirming news & $10.11 \%$ & $9.64 \%$ & $8.94 \%$ & $8.39 \%$ & $8.26 \%$ & $7.71 \%$
\end{tabular}

Panel B. Marginal Effects on the Probability of Individual Institutions Continuing Their Pre-Announcement Trading Directions After Announcements

\begin{tabular}{|c|c|c|c|c|c|c|}
\hline & $\overline{P r}\left(\mathrm{CO}_{[2,20]}\right)$ & $\operatorname{Pr}\left(\mathrm{CO}_{[21,40]}\right)$ & $\operatorname{Pr}\left(\mathrm{CO}_{[41,60]}\right)$ & $\operatorname{Pr}\left(\mathrm{CO}_{[61,80]}\right)$ & $\operatorname{Pr}\left(\mathrm{CO}_{[81,100]}\right)$ & $\operatorname{Pr}\left(\mathrm{CO}_{[101,120]}\right)$ \\
\hline$I\left(\operatorname{SUE} \times \operatorname{CAIID}_{[-40,-1]}>0\right)$ & $\begin{array}{c}0.5394 * * * \\
(0.0051)\end{array}$ & $\begin{array}{l}0.5131^{* * *} \\
(0.0049)\end{array}$ & $\begin{array}{l}0.4764^{* * * *} \\
(0.0046)\end{array}$ & $\begin{array}{l}0.4467 * * * \\
(0.0037)\end{array}$ & $\begin{array}{c}0.4402 * * * \\
(0.0034)\end{array}$ & $\begin{array}{c}0.4123 * * * \\
(0.0026)\end{array}$ \\
\hline $\operatorname{CAIID~}_{[-40,-1]}$ & $\begin{aligned}-0.0058^{* * *} & (0.0002)\end{aligned}$ & $\begin{array}{l}-0.0055^{* * *} \\
(0.0002)\end{array}$ & $\begin{array}{l}-0.0046^{* * *} \\
(0.0002)\end{array}$ & $\begin{array}{l}-0.0041^{* * *} \\
(0.0001)\end{array}$ & $\begin{array}{c}-0.0039 * * * \\
(0.0001)\end{array}$ & $\begin{array}{l}-0.0032 * * * \\
(0.0001)\end{array}$ \\
\hline $\operatorname{CAR}_{[-40,-1]}$ & $\begin{array}{c}0.0054 * * * \\
(0.0012)\end{array}$ & $\begin{array}{l}0.0027 * * \\
(0.0010)\end{array}$ & $\begin{array}{c}0.0045 \\
(0.0010)\end{array}$ & $\begin{array}{c}0.0062 * * * \\
(0.0011)\end{array}$ & $\begin{array}{c}0.0072 * * * \\
(0.0011)\end{array}$ & $\begin{array}{c}0.0097 \\
(0.0011)\end{array}$ \\
\hline $\begin{array}{l}\text { Control variables } \\
\text { Pseudo } R^{2}(\%)\end{array}$ & $\begin{array}{c}\text { Yes } \\
24.57\end{array}$ & $\begin{array}{c}\text { Yes } \\
23.79\end{array}$ & $\begin{array}{c}\text { Yes } \\
22.76\end{array}$ & $\begin{array}{c}\text { Yes } \\
22.00\end{array}$ & $\begin{array}{c}\text { Yes } \\
21.83\end{array}$ & $\begin{array}{c}\text { Yes } \\
21.23\end{array}$ \\
\hline$I\left(\operatorname{SUE} \times \operatorname{CAIID}_{[-40,-1]}>0\right)$ & $\begin{array}{c}0.5299 * * * \\
(0.0050)\end{array}$ & $\begin{array}{c}0.5039 * * * \\
(0.0048)\end{array}$ & $\begin{array}{c}0.4680 * * * \\
(0.0045)\end{array}$ & $\begin{array}{c}0.4380 * * * \\
(0.0036)\end{array}$ & $\begin{array}{c}0.4319 * * * \\
(0.0034)\end{array}$ & $\begin{array}{c}0.4029 * * * \\
(0.0026)\end{array}$ \\
\hline $\begin{array}{r}\mathbf{I}\left(\operatorname{SUE} \times \operatorname{CAIID}_{[-40,-1]}>0\right) \\
\times|\mathrm{SUE}|\end{array}$ & $\begin{array}{c}0.0026^{* * *} \\
(0.0002)\end{array}$ & $\begin{array}{c}0.0024 * * * \\
(0.0001)\end{array}$ & $\begin{array}{c}0.0020^{* * *} \\
(0.0002)\end{array}$ & $\begin{array}{c}0.0020^{* * *} \\
(0.0001)\end{array}$ & $\begin{array}{c}0.0019 * * * \\
(0.0001)\end{array}$ & $\begin{array}{c}0.0020^{* * *} \\
(0.0001)\end{array}$ \\
\hline $\operatorname{CAIID}_{[-40,-1]}$ & $\begin{aligned}-0.0058^{* * *} & (0.0002)\end{aligned}$ & $\begin{array}{l}-0.0055^{* * *} \\
(0.0002)\end{array}$ & $\begin{array}{l}-0.0046^{* * *} \\
(0.0002)\end{array}$ & $\begin{array}{l}-0.0041^{* * *} \\
(0.0001)\end{array}$ & $\begin{array}{c}-0.0040 * * * \\
(0.0001)\end{array}$ & $\begin{array}{l}-0.0032 * * * \\
(0.0001)\end{array}$ \\
\hline $\operatorname{CAR}_{[-40,-1]}$ & $\begin{array}{c}0.0057 * * * \\
(0.0012)\end{array}$ & $\begin{array}{c}0.0028 * * * \\
(0.0010)\end{array}$ & $\begin{array}{c}0.0047 * * * \\
(0.0010)\end{array}$ & $\begin{array}{l}0.0063 * * \\
(0.0010)\end{array}$ & $\begin{array}{c}0.0074 * * * \\
(0.0010)\end{array}$ & $\begin{array}{c}0.0098 * * * \\
(0.0011)\end{array}$ \\
\hline |SUE $\mid$ & $\begin{array}{c}-0.0010^{* * *} \\
(0.0001)\end{array}$ & $\begin{array}{c}-0.0008 * * * \\
(0.0001)\end{array}$ & $\begin{array}{c}-0.0007 * * * \\
(0.0001)\end{array}$ & $\begin{array}{c}-0.0006^{* * *} \\
(0.0001)\end{array}$ & $\begin{array}{c}-0.0007 * * * \\
(0.0001)\end{array}$ & $\begin{array}{c}-0.0006^{* * *} \\
(0.0001)\end{array}$ \\
\hline Control variables & Yes & Yes & Yes & Yes & Yes & Yes \\
\hline Pseudo $R^{2}(\%)$ & 24.58 & 23.80 & 22.77 & 22.01 & 21.84 & 21.24 \\
\hline
\end{tabular}


TABLE 10

The PEAD Anomaly and the Role of Institutional Trading

Table 10 demonstrates the existence of the PEAD anomaly and the role of institutional trading in contributing to the PEAD anomaly, using the following regressions:

$$
\begin{gathered}
\operatorname{CAR}_{\left[t_{1}, t_{2}\right]}=\beta_{0}+\beta_{1} \operatorname{SUE}+\beta_{2} \operatorname{CAR}_{[-40,-1]}+\sum_{i=1}^{12} \gamma_{i} \mathrm{CV}_{i}+\varepsilon \\
\operatorname{CAR}_{\left[t_{1}, t_{2}\right]}=\beta_{0}+\beta_{1} \operatorname{SUE} \times \mathbf{I}\left(\operatorname{SUE} \times \operatorname{CAID}_{[-40,-1]}>0\right)+\beta_{2} \operatorname{SUE} \times \mathbf{I}\left(\operatorname{SUE} \times \operatorname{CAID}_{[-40,-1]} \leq 0\right)+\beta_{3} \mathrm{CAR}_{[-40,-1]}+\sum_{i=1}^{12} \gamma_{i} \mathrm{CV}_{i}+\varepsilon
\end{gathered}
$$

where $\mathrm{CAR}_{\left[t_{1}, t_{2}\right]}$ is the cumulative abnormal return from day $t_{1}$ to day $t_{2}, \operatorname{CAID}_{[-40,-1]}$ the cumulative abnormal institutional demand over day -40 to day -1 , SUE the standardized unexpected earnings. In the regressions, $\boldsymbol{I}\left(\operatorname{CAID}_{[-40,-1]} \times \mathrm{SUE}>0\right)$ is the dummy variable of confirming earnings news, i.e., $\mathrm{CAID}_{[-40,-1]}$ is on the same side of SUE, while $I\left(\operatorname{CAID}_{[-40,-1]} \times \mathrm{SUE} \leq 0\right)$ is the dummy variable of disconfirming earnings news. Control variables $\mathrm{CV}_{i}$ are estimated in the year prior to the earnings announcements and they include stock size, which is the logarithm of the average daily market capitalization, stock price, stock illiquidity, market beta, idiosyncratic volatility, bid-ask spread, institutional ownership, analyst coverage, book-to-market ratio, probability of information-based trading, firm age, and dispersion in analyst forecasts of the stock. Standard errors are clustered by stock and calendar quarter (Petersen (2009)) and the 2-way cluster-robust tstatistics are reported in parentheses. Symbols $* * *,{ }^{*}$ and $*$ indicate significance at the $1 \%, 5 \%$, and $10 \%$ levels, respectively.

SUE

SUE $\times \boldsymbol{I}\left(\operatorname{CAID}_{[-40,-1]} \times \operatorname{SUE} \leq 0\right)$

$\operatorname{CAR}_{[-40,-1]}$

Control variables

$R^{2}(\%)$

Adjusted $R^{2}(\%)$

\section{$\frac{\mathrm{CAR}_{[2,60]}}{0.0017 * * *}$}

(2.707)

\begin{tabular}{|c|c|c|c|}
\hline \multicolumn{2}{|c|}{$\mathrm{CAR}_{[2,30]}$} & \multicolumn{2}{|c|}{$\mathrm{CAR}_{[31,60]}$} \\
\hline $\begin{array}{c}0.0016 * * * \\
(4.394)\end{array}$ & & $\begin{array}{c}0.0001 \\
(0.216)\end{array}$ & \\
\hline & $\begin{array}{c}0.0010^{* * *} \\
(3.046)\end{array}$ & & $\begin{array}{l}-0.0004 \\
(-0.615)\end{array}$ \\
\hline & $\begin{array}{c}0.0020^{* * *} \\
(4.627)\end{array}$ & & $\begin{array}{l}0.0005 \\
(1.201)\end{array}$ \\
\hline $\begin{array}{c}-0.0492 * * * \\
(-3.481)\end{array}$ & $\begin{array}{c}-0.0488^{* * *} \\
(-3.462)\end{array}$ & $\begin{array}{l}-0.0096 \\
(-0.605)\end{array}$ & $\begin{array}{l}-0.0093 \\
(-0.586)\end{array}$ \\
\hline Yes & Yes & Yes & Yes \\
\hline 0.61 & 0.62 & 0.12 & 0.14 \\
\hline 0.59 & 0.60 & 0.11 & 0.12 \\
\hline
\end{tabular}

$\begin{array}{cccc} & 0.0006 & & -0.0015^{* * *} \\ & (0.931) & & (-2.742) \\ & & & \\ & 0.0025^{* * *} & & -0.0001 \\ & (3.787) & & (-0.202) \\ -0.0587^{* * *} & -0.0581^{* * *} & -0.0007 & -0.0002 \\ (-2.781) & (-2.757) & (-0.019) & (-0.007) \\ & & & \\ \text { Yes } & \text { Yes } & \text { Yes } & \text { Yes } \\ 0.47 & 0.50 & 0.86 & 0.88 \\ 0.45 & 0.48 & 0.85 & 0.86\end{array}$

